Pittsburgh University School of Law

Scholarship@PITT LAW

1996

\title{
Last Writes? Re-Assessing the Law Review in the Age of Cyberspace
}

\author{
Bernard J. Hibbitts \\ University of Pittsburgh School of Law, hibbitts@pitt.edu
}

Follow this and additional works at: https://scholarship.law.pitt.edu/fac_articles

Part of the Law and Philosophy Commons, Law and Society Commons, Legal Education Commons, Legal Writing and Research Commons, and the Science and Technology Law Commons

\section{Recommended Citation}

Bernard J. Hibbitts, Last Writes? Re-Assessing the Law Review in the Age of Cyberspace, 71 New York University Law Review 615 (1996).

Available at: https://scholarship.law.pitt.edu/fac_articles/126

This Article is brought to you for free and open access by the Faculty Publications at Scholarship@PITT LAW. It has been accepted for inclusion in Articles by an authorized administrator of Scholarship@PITT LAW. For more information, please contact leers@pitt.edu, shephard@pitt.edu. 


\title{
ARTICLE \\ LAST WRITES? \\ REASSESSING THE LAW REVIEW IN THE AGE OF CYBERSPACE
}

\author{
BERNARD J. HIBBITTS*
}

\begin{abstract}
Professor Hibbitts reassesses the history and future of the law review in light of changing technological and academic conditions. He analyzes why law reviews developed in the late nineteenth and early wentieth centuries and shows how three different waves of criticism have reflected shifting professorial, professional, and pedagogical concerns about the genre. Recent editorial reforms and the inauguration of on-line services and electronic law journals appear to solve some of the law review's traditional problems, but Professor Hibbitts suggests that these procedural and technological modifications leave the basic criticisms of the law review system unmet. In this context, Professor Hibbitts proposes that legal writers self-publish
\end{abstract}

* Professor of Law, University of Pittsburgh. B.A. (Juris.), 1983, Oxford University; LL.B., 1984, Dalhousie University; LL.M., 1986, University of Toronto; LLM., 1988, Harvard Law School. E-mail: <hibbitts@law.pitt.edu>; Web page: <http:/inww.law.pitt. edu/hibbitts/>. I am especially grateful to Welsh White, Anthony D'Amato, Brian Doyle, Robert Hamilton, Mark Ramseyer, Gary Rosin, and Paul Ginsparg for their written comments on previous versions of this Article. William Curley made many invaluable contributions to the piece as my research assistant. Responsibility for the views contained hereinas well as for any mistakes or errors of interpretation-is, of course, mine alone.

This printed document is a slightly revised and more heavily annotated version of Bernard J. Hibbitts, Last Writes? Re-assessing the Law Review in the Age of Cyberspace, Version 1.0, first posted on the World Wide Web on February 5, 1996 and currently archived at $<\mathrm{http}: / / \mathrm{www}$.law.pitt.edu/hibbitts/arclw.htm>. In printed form, the Article neeessarily lacks the hypertext and multimedia enhancements of its electronic original and appears here without its supporting structure, which included a direct e-mail line to the author, a collection of e-mailed reader comments together with the author's responses to the same, a "counter" and weekly summary of reader downloads, and connections to related sites mentioning or featuring the Article as a hypertext "link".

Extended solicited commentary on Version 1.0 of Last Writes? (with my response) may be found in print in volume 29 of the Akron Law Review (Special Issue, forthcoming 1996) and will shortly be accessible on the World Wide Web via the Akron Law Review's web site, <http://www.uakron.edu/law/alr/alr.html $>$. The latest electronic version of Last Writes? itself (at this printing, Version 1.1) is now available on the Web at <http:ll www.law.pitt.edu/hibbitts/lastrev.htms.

I cannot end this note without giving due credit to the members of the Editorial Board of the New York University Law Review, and especially to Senior Articles Editor Victor Hou and Articles Editor Deborah Levi. In every stage of the selection and editorial process, they conducted themselves in a highly considerate, cooperative, pleasant, and professional fashion, upholding what is best (if, according to many accounts, not universal) in the law review tradition. They reacted to the message of this Article with grace, interest, and even enthusiasm, despite the depth of the challenge it posed to the legitimacy and future of their formal roles. Whether or not the law review ultimately perishes as an institution in the age of cyberspace, this may have been its finest hour. 
on the World Wide Web, as he did in a previous version of this Article. This strategy, Professor Hibbitts argues, would give legal writers more control over the substance and form of their scholarship, would create more opportunities for spontaneity and creativity, and would promote more direct dialogue among legal thinkers. It would also sound the death knell for law reviews in their present form.**

\section{INTRODUCTION: HaIL!-AND FAREWELL?}

The next decade could witness the end of the law review as we know it.

At first glance, this contention might seem implausible-after all, the law review is the supreme institution of the contemporary American legal academy. Virtually all accredited law schools have one; quite a few have several. Law schools depend upon law reviews for publicity and prestige. Law professors depend upon law reviews for publication and promotion. Law students depend upon law reviews for education and eventual employment.

The law review, however, is hardly an inevitable institution. It emerged in the late nineteenth and early twentieth centuries as the product of a fortuitous interaction of academic circumstances and improvements in publishing technology. 1 Today, new academic circumstances (not least among which is an increased professorial dissatisfaction with law reviews themselves) ${ }^{2}$ and new computermediated communications technologies (e.g., on-line services and the Internet) are coming together in a way that may soon lead to the demise of the familiar law review in favor of a more promising system of scholarly communication.

In this Article, I undertake a comprehensive reassessment of the law review from the perspective of the present age of cyberspace. In Part I, I begin this reassessment by investigating the academic and

** The New York University Law Review has always been mindful of its role in shaping legal discourse and its continuing obligation to be responsive to the changing legal environment. Throughout its history, at each successive wave of criticism that Professor Hibbitts identifies, the Law Review has published examinations into the limitations of studentedited journals. See, e.g., Stanley H. Fuld, A Judge Looks at the Law Review, 28 N.Y.U. L. Rev. 913 (1953); Samuel Nirenstein, The Law Review and the Law School, 1 Ann. Rev. L. Sch. N.Y.U. 31 (1924). While our traditional publication policy has been to accept original works that have never been published, an exception was made for Professor Hibbitts's Article. In a novel copyright agreement, we have retained the copyright to the print and on-line versions of the Article while Professor Hibbitts has retained all other on-line rights to his Article and its subsequent electronic permutations. Our print publication of the Article reflects our respect for Professor Hibbitts's scholarship and the continuing commitment of the Law Review to extend the range of legal discourse. For now at least, rumors of our demise are still greatly exaggerated.

1 See infra Part I.

2 See infra notes $116-97$ and accompanying text. 
technological conditions that initially joined to generate the genre. In Part II, I trace the course that criticism of the law review has taken since the institution's debut, showing how criticisms have grown in number, range, and intensity to reach their current crescendo. I explore why various criticisms arose when they did and evaluate erstwhile (and, as it turns out, largely failed) attempts at reforming the law review system for the benefit of its academic and professional constituencies. In Part III, I examine how new computer-mediated communications technologies embodied in WESTLAW, LEXIS, and the Internet's so-called "electronic journals" have subtly begun to change and improve the law review system, even if those particular services do not and cannot cure the system's more profound ills. In Part IV, I offer a "modest proposal" for the electronic self-publishing of legal scholarship that would use the full potential of today's computer technology to overcome the editorial and material limitations of the law review format while providing legal scholars with an unprecedented range of intellectual and professional opportunities. In the Conclusion to this Article, I consider what legal scholars, law school deans and faculties, the American Association of Law Schools, and even the editors of law reviews themselves might do to accelerate or at least accommodate the transition to the proposed system of electronic selfpublication.

\section{I \\ Hello to LAw Reviews}

The standard story of the rise of the American law review is so familiar as to be almost legendary. In 1887, after attempts to create student-edited law journals at Albany and Columbia had already failed, 3 a group of ambitious students at the Harvard Law Schoolamong them the future legal scholars John Wigmore and Joseph Beale-approached Professor James Barr Ames ${ }^{4}$ of the Harvard law faculty to suggest the inauguration of a school-sponsored legal periodical that would contain not only student-written essays and case comments, but also scholarly papers contributed by Harvard law professors and other prominent members of the bar. The students hoped that in addition to providing a new platform for legal scholarship, such a periodical would spread the word about the Harvard Law School and especially about the case method of instruction that they

3 See generally Michael I. Swygert \& Jon W. Bruce, The Historical Origins, Founding, and Early Development of Student-Edited Law Reviews, 36 Hastings LJ. 739, 764-69 (1985) (chronicling formation and subsequent failure of the two publications).

4 On Ames's supportive role in the creation of the Harvard Law Review, see id. at 771-72. 
and their faculty mentors were pioneering. Seeing the wisdom of the proposal, Ames agreed to act as the law review's advisor and first contributor. ${ }^{5}$ The newly formed Harvard Law School Alumni Association provided significant financial backing, and the Harvard Law Review was born. The Review proved so successful that it soon spawned imitators among other American law schools that aspired to Harvard's growing status and prestige. ${ }^{6}$ Within a few decades, the law review had become a fixture of the American legal landscape, with dozens of law reviews in publication, and many more on the way. ${ }^{7}$

As a rendition of specific facts, this story is not inaccurate; but as an explanation of the initial development and popularization of the law review, it is nonetheless inadequate. The account has three fundamental failings. First, in focusing (however understandably) on the particularities and personalities of Harvard, it downplays the extent to which the law review served the general interests of the universitybased law school as an institution seeking to advance itself in late nineteenth- and early twentieth-century America. Second, the traditional story totally disregards contemporary technological developments in the printing and publishing industry that in the late nineteenth century made law school sponsorship of legal periodicals conceptually plausible and financially practicable for the first time. Third, even as confined to Harvard, the familiar story presents the law review as the creature of narrow legal considerations where there is at least circumstantial evidence to suggest that broader scholarly concerns might also have animated Ames, the colleagues who supported him, and perhaps his precocious band of law students. As a result of these three shortcomings, the law review has been portrayed more as a happy serendipity or a legal peculiarity than as a complex but rational product of its time. In the remainder of this section, I will argue for the last of these interpretations.

In late nineteenth- and early twentieth-century America, university-based law schools were not nearly as populous, powerful, and prestigious as they are today. They were admittedly not new: law had been taught at Harvard as early as 1815 , and the university had

5 Id. at $770-71$.

6 Afton Dekanal, Faculty-Edited Law Reviews: Should the Law Schools Join the Rest of Academe?, 57 UMKC L. Rev. 233, 235 (1989) ("[F]or virtually all schools except Harvard, student-edited law journals came into being because that is what Harvard did."); Lyman P. Wilson, The Law Schools, the Law Reviews and the Courts, 30 Cornell L.Q. 488, 493 (1945) ("[B]ecause in education as elsewhere there is such a thing as "keeping up with the Joneses,' each new school and each of the older ones that did not already have a law review felt the urge to start one.").

7 See John J. McKelvey, The Law School Review, 1887-1937, 50 Harv. L. Rev. 868, 882 (1937) (citing multiplication of law reviews after Harvard's success). 
operated a separate law school since 1817.8 Neither were universitybased law schools all that rare anymore; by the late 1880 s, there were over forty-five of them. ${ }^{9}$ For all their years and their numbers, however, the law schools were, by and large, marginal institutions. They were marginal professionally: universally into the $1890 \mathrm{~s}$, and in many regions of the country through the 1900 s, most American lawyers still received their education by the more traditional means of apprenticeship. ${ }^{10}$ In this context, formal legal education was seen (at best) as a supplement to office training, not a substitute for it."11 Universitybased law schools were also marginal academically. Many (such as Harvard) existed on the intellectual and physical outskirts of university campuses. Most counted for little in their universities' overall academic reputations, ${ }^{12}$ and sometimes for less in their budgets. ${ }^{13}$

In this context, ambitious law professors sought ways to advance their institutions, their students, and themselves. They had several implicit (and sometimes explicit) goals. First, they wanted to provide their students with a superior form of legal training that would positively distinguish those students from students trained only in law firms. ${ }^{14}$ Second, they wanted to develop their ties with the practicing

8 Robert Stevens, Law School: Legal Education in America from the 1850 s to the 1980 s, at 4 (1983).

9 In 1880, there were 46 university-based law schools in the United States; in 1890 , there were 50. See Alfred Z. Reed, Training for the Public Profession of the Law $445 \mathrm{tbl.7}$ (1921) (cataloguing law schools by type of organization from 1790-1921).

10 See Stevens, supra note 8, at 24 ("The vast majority of the legal profession until the turn of the century still experienced only on-the-job legal education.").

11 "In 1887, ... [m] [my [law schools] were merely adjuncts or supplementary agencies, in the creation of lawyers, to the law offices ...." McKelvey, supra note 7, at 878; see also William Johnson, Schooled Lawyers: A Study in the Clash of Professional Cultures 49 (1978) (discussing "[t]he limited and supplementary role that law schools played in legal training").

12 See Stevens, supra note 8, at 35, 37 (explaining that nineteenth-century law schools were mostly trade schools and noting that admissions standards for law schools were lower than those for undergraduate programs).

13 See Reed, supra note 9, at 183 (noting that most law schools, except Harvard and University of Virginia, did not receive effective financial support from their universities).

14 In the latter half of the nineteenth century, American law professors and law schools repeatedly premised their existence on their ability to create superior lavyers. In its cata$\log$ for 1858-1859, for instance, New York University's Law Department rejected office training as an environment where (as opposed to law school),

"[students] generally pursue their studies unaided by any real instruction, or examination, or explanation. They imbibe error and truth, principles which are still in force with principles which have become obsolete; and when admitted to practice, they find, often at the cost of their unfortunate clients, that their course of study has not made them sound lawyers or correct practitioners."

Stevens, supra note 8, at 22 (quoting Law Department, New York University, Annual Announcement of Lectures (1858-1859)). 
bar in a way that would increase the legitimacy of their schools and enhance their own reputations in the professional legal community where most of them still worked part-time. ${ }^{15}$ Third, they wanted to strengthen their connection with alumni whose support promoted law school solvency, professional goodwill, and the employment of law graduates. ${ }^{16}$ Fourth, they wanted to improve their academic status in their respective university settings. ${ }^{17}$

While legal academics were pursuing these goals, contemporary publishing technology was changing. In the last decades of the nineteenth century, new high-speed rotary printing presses came into general use. ${ }^{18}$ Paper-making processes accelerated at the same time, thanks to the widespread substitution of ground woodpulp for rags. ${ }^{19}$ Together, these developments pushed printing and paper costs to unprecedentedly low levels. ${ }^{20}$ Taking advantage of the savings, established and new publishers flooded a waiting American market with inexpensive books and magazines. In 1880, 2076 new books were published in the United States; in 1884, over 4000; in 1895, over 5400.21 There were approximately 3300 American periodicals in publication in 1885 ; by 1890 that number had risen to 4400 ; by 1895 , there were approximately 5100 being produced nationwide. 22 The explosion in the available volume of printed matter became a subject of public comment and even public concern. In 1895, the editor of The Nation observed that the "multiplication and cheapening of periodical literature within the past five years have been extraordinary."23 In 1896,

15 See, e.g., George W. Pepper, Philadelphia Lawyer: An Autobiography 48 (1944) (recalling University of Pennsylvania Law School in 1887, when Pepper was a first-year student there: "There was increasing co-operation between the offices of the bar and the law school. The race of full-time professors of law was in its infancy. In almost all cases the lecturers in the schools were active practitioners who had a flair for teaching.").

16 Some law schools, such as Columbia, had benefited from the existence of formal alumni associations as early as the 1860s. See Foundation for Research in Legal History, A History of the School of Law, Columbia University 403 n.57 (1955).

17 See, e.g., Stevens, supra note 8, at 35-72 (commenting on Dean Langdell's attempts to raise academic standards and gain respectability at Harvard between 1870 and 1895).

18 See Alfred M. Lee, The Daily Newspaper in America: The Evolution of a Social Instrument 118-21 (1937); Hellmut Lehmann-Haupt, The Book in America: A History of the Making and Selling of Books in the United States 162-65 (1951) (tracing development of large cylinder press for newspaper printing).

19 See generally Lee, supra note 18 , at $100-03$ (detailing newspapers' transition to woodpulp newsprint in late 1860 s and early 1870 s); Lehmann-Haupt, supra note 18, at 166 70 (tracing technological changes and growth in paper-making industry in ninetcenth century).

20 See generally Lee, supra note 18 , at $104,118-19$.

212 John Tebbel, A History of Book Publishing in the United States 676, 679, 687 (1975).

22 Frank L. Mott, A History of American Magazines 1885-1905, at 11 (1957).

23 Some Magazine Mysteries, 61 Nation 342, 342 (1895). 
the editor of another journal concluded (somewhat ironically, in retrospect) that "this is a book-enslaved generation. Too many books, too many newspapers, too many magazines-too little reflection, too little originality." 24

Law was hardly immune from the lure of cheap print. The number of law books published each year hit record levels in the 1880 s and 1890s. ${ }^{25}$ In 1880, 62 new law books were published in the United States; in 1882, 261; in 1889, 410; and in 1896, 507.26 The number of reprints published also increased dramatically. Lawyers inevitably complained about the burgeoning mass of texts and precedents. In 1882, Chicago attorney J.L. High, writing in the American Law Review, called the increase in materials "appalling": "[S]o far from strengthening the foundations upon which our jurisprudence as a system is based, [the increase] has a well-defined tendency to weaken them by the substitution of precedents for principles in the practical administration of justice."27 For fear of missing something important or being at a disadvantage, however, most lawyers continued to buy and stock as many law books as they could afford.

The new technology lowered the cost of printing legal periodicals to a point where even relatively impecunious law schools could sponsor them. ${ }^{28}$ The flood of periodicals which the new technology facilitated also helped to create an intellectual and cultural environment in which publishing a periodical seemed unremarkable, even for institutions that would not previously have considered such an ostensibly ambitious and even pretentious undertaking. The fact that a schoolsponsored law journal might be feasible and conceivable, however, was not enough to ensure that such an experiment would actually be attempted. That final step required purpose as well as opportunity.

Unfortunately, there is precious little before-the-fact evidence of precisely which positive factors prompted law professors in a signifcant number of American law schools to support the inauguration of school-sponsored law reviews in the late nineteenth and early twentieth centuries. Contemporary circumstances and the range of formal, after-the-fact justifications for publication strongly suggest, however,

24 Irving Browne, Too Many Books, 8 Green Bag 83, 83 (1896).

25 See generally Cheap Books, Am. L.J., June 21, 1884, at 105.

262 Tebbel, supra note 21, at 676-77, 682, 689 .

27 J.L. High, What Shall be Done with the Reports?, 16 Am. L. Rev. 429, 435, 439 (1882); see also Robert Hughes, Law Reporting, 1 Va. L. Reg. 309 (1885); R.S. Taft, Precedents, 3 U. L. Rev. 197, 198 (1897).

28 The Michigan Law Review, for instance, would premier in 1901 with an \$800 loan from the School's Board of Regents-not an insignificant sum at the time, but at least within the realm of institutional possibility. E. Blythe Stason, The Lav Reviev-Its First Fifty Years, 50 Mich. L. Rev. 1134, 1134 (1952). 
that law professors at these schools believed that law reviews were capable of advancing their aforementioned institutional and personal goals in a variety of ways. First, a law review could further the education of law students. ${ }^{29}$ At the most general level, law students reading their school's law review would presumably benefit from the writings of their professors, and perhaps also from those of their student colleagues. If law students were actually put in charge of a law review, its educational and ultimately professional value to them would be greater still. Acting as editors, they would gain by evaluating and polishing the contributions of law professors and practitioners. As contributors in their own right, their attention would be focused on recent developments in the case law, and they would gain proficiency in legal analysis, research, and writing. Insofar as few if any of these opportunities were available to apprentices working in law firms, working on a law review would make law school graduates uniquely capable in an American legal environment increasingly saturated with printed precedents, statutes, and texts. ${ }^{30}$ As a result, those graduates would be more attractive to potential employers, and the schools and professors that produced them would gain prestige and profit.

Second, making law school graduates more attractive to law firms by virtue of their experience on school-sponsored law journals could strengthen the connection between law schools and the bar. ${ }^{31}$ Not only could a student-edited law review eventually provide the bar with a pool of specially trained recruits, but-assuming it were staffed by the law students with the highest grades-it could also provide a convenient criterion by which hiring attorneys could identify the best and the brightest law graduates. This criterion appeared increasingly attractive once schools such as Harvard eliminated the formal "Honors" programs which had once served the same "streaming" function. ${ }^{32}$ With or without student editing, a school-sponsored law journal could

29 For justifications of law reviews citing this capability, see Samuel Nirenstein, The Law Review and the Law School, 1 Ann. Rev. L. Sch. N.Y.U. 31, 32-34 (1924) (Annual Review of the Law School of New York University, later New York University Law Review); Edwin H. Woodruff, The Cornell Law Quarterly, 1 Cornell L.Q. 27, 28 (1915); Editors' Note, 1 Md. L. Rev. 3, 3 (1901); Editors' Note, 1 Mich. L.J. 25 (1892); Introductory, 1 Counsellor 16 (1891) (New York Law School).

30 See William P. LaPiana, Logic and Experience: The Origin of Modern American Legal Education 100 (1994) (explaining that law review experience was valuable in a changing legal environment where written briefs and opinions were replacing oratory as the characteristic form of legal communication).

31 On the general role of the law review in promoting this connection, see, e.g., Henry J. Fletcher, Foreword, 1 Minn. L. Rev. 63, 63 (1917).

32 See LaPiana, supra note 30 , at 100 (describing this process at Harvard). 
provide practitioners with at least two useful professional services: 33 it could serve as an additional medium through which they could communicate with other practitioners, and it could be a source from which they could regularly glean information on the broader implications of new cases and new legislation. At a time when the bar was being buried with more printed information and material than it could readily assimilate, this latter function was potentially critical: a law review could serve as a law digest, potentially saving busy practitioners both the time and the money they would otherwise have spent on rapidly outdated treatises, reports, and statutes. Of course commercial legal journals and digests were already available, ${ }^{34}$ but the mass of information descending on the American legal community at the turn of the century was such that more law journals offering analyses, updates, and reviews were always welcome. A law school that chose to publish such a journal could gain increased professional recognition and influence, as could the law professors whose writings appeared in its pages.

Third, a law review could address a law school's institutional need to gain and keep the support of alumni by providing a product that would bring news of the school to their attention on a regular basis. More proactively, it could also provide a forum in which they could publish, correspond, and generally maintain ties with one another. ${ }^{35}$ A school-sponsored law journal promised to be particularly useful as a bonding mechanism when a law school's graduates were scattered over a broad geographical area (as was already the case in a number of prominent instances in the late nineteenth century), ${ }^{36}$ limiting the opportunities for face-to-face meeting and regular conversation. Of course, the more connected alumni felt to each other and to their alma mater, the more likely they would be to hire their alma mater's graduates, send their own sons (and even daughters) there, recommend the school to friends, and (most importantly) contribute to its coffers.

Finally, a school-sponsored law journal could enhance a law school's academic and scientific reputation. In late nineteenth-

33 For justifications citing the law review's capacity to aid practitioners, see Editors" Note, 1 S. L.Q. 45, 45 (1916) (Tulane Law School); Editors' Note, 1 WV. Res. L.J. 18, 18-19 (1895); Introductory, supra note 29; Notes, 1 Harv. L. Rev. 35, 35 (1887) [hereinafter Harvard Notes]; Frederic C. Woodward, Editorial Notes, 1 Ill. L. Rev. 39, 39-40 (1906).

34 For example, the Albany Law Journal, American Law Review, and Central Law Journal.

35 For justifications citing the law review's role in facilitating alumni communications, see Editors' Note, 1 Yale L.J. 30, 30-31 (1891); Harvard Notes, supra note 33, at 35; Woodruff, supra note 29 , at 28.

36 See, e.g., Philip Girard, The Roots of a Professional Renaissance: Lawyers in Nova Scotia 1850-1910, 20 Man. LJ. 148, 165 tbl. IV (1991) (showing numbers of students from Nova Scotia and New Brunswick who attended Harvard Law School from 1840-1929). 
century America, the focus of the academic community was starting to shift from teaching to scholarship. The German model of postsecondary education that was becoming increasingly influential in the United States around this time encouraged universities to reinvent themselves as producers (not merely conveyors) of research and learning that would stimulate progress and reform. ${ }^{37}$ In 1876 , Johns Hopkins University was established as the first American "research university."38 Consistent with the new emphasis on research, academics in a wide range of disciplines turned to writing. Universities and learned societies created numerous journals to contain the rush of new scholarship, which could not be absorbed (and in many instances would not have been accepted) by then-existing commercial or learned periodicals. ${ }^{39}$ The declining cost of print facilitated and further stimulated this process. The last quarter of the nineteenth century witnessed the birth of such scholarly stalwarts as the American Journal of Mathematics (1878), the American Chemical Journal (1879), the American Journal of Philology (1880), the Journal of the American Medical Association (1883), the Political Science Quarterly (1886), Modern Language Notes (1886), the American Journal of Psychology (1887), the Journal of Political Economy (1892), the American Historical Review (1895), the Journal of Physical Chemistry (1896), and the American Journal of Sociology (1896). Ultimately, a variety of universities set up their own presses to facilitate the distribution of their faculties' research products. Predictably, Johns Hopkins led the way in 1891, followed by Chicago (1892), Columbia (1893), and the University of California (1893)..$^{40}$

All this activity created an environment in which intellectual respectability was increasingly associated with the sponsorship of journals and the practice of publication. 41 In this context, the inauguration of a school-sponsored law review could offer a

37 For a discussion of the influence of German universities on American academic life during the late nineteenth century, see Laurence R. Veysey, The Emergence of the American University 125-33 (1965).

38 Id. at 158.

39 Note, for instance, this comment by the first President of Johns Hopkins, Danicl Gilman, looking back from 1902 on the circumstances prevailing in 1876: "When this university began, the opportunities for scientific publication in this country were very meagre. The American Journal of Science was the chief repository for short and current papers. The memoirs of a few learned societies came out at slow intervals and could not be frecly opened to investigators." Dennis P. Carrigan, The Political Economy of Scholarly Com. munication and the American System of Higher Education, $15 \mathrm{~J}$. Acad. Librarianship 332. 334 (1990) (quoting Daniel Gilman).

40 See Frederick Rudolph, The American College and University: A History 407 (1990) (discussing emergence of organized university presses).

41 Id. at 406. 
university-based law school an unprecedented academic opportunity. As the patron of a "learned" journal providing a needed forum for its faculty's scholarship ${ }^{42}$ outside the traditional confines of treatises ${ }^{43}$ and commercial legal periodicals, ${ }^{44}$ a law school could at last make common academic cause with other progressive departments and professional schools on its campus (even if its own journal were studentedited). ${ }^{45}$ Even more fundamentally, it could demonstrate that the

42 For justifications referring to law reviews as forums for faculty scholarship, see Nirenstein, supra note 29, at 32; Announcement. 1 Mich. L. Rev. 58, 58 (1902); Editors' Note, 1 Geo. L.J. 50 (1912); Orrin K. McMurray, Introductory Note, 1 Cal. L. Rev. 46, 48 (1912).

43

[W]ithout the law review, the law teacher who was imbued with an urge for expression unsated by the confection of classroom notes would have found little other outlet than that afforded by the treatise. But the treatise is a medium not open to everyone. It demands a substantial investment which the commercial publisher is willing to make only if the assured position of its author (or, occasionally, the timeliness of its subject) affords some guaranty of an adequate market.

David F. Cavers, New Fields for the Legal Periodical, 23 Va. L. Rev. 1, $2-3$ (1936).

44 One commentator later said, "Were it not for the Law Review, many epoch-making articles might never have been written, or if written, would never have had widespread influence. In the issues of the Law Review, they were circulated, and were read by all." Nirenstein, supra note 29, at 32.

45 Although not all early law reviews were edited by law students (the Michigan Law Review (1902) and Northwestem's Illinois Law Reviewy (1906) were two particularly prominent-although hardly the only-exceptions), student editing dominated the genre from the outset. The reasoning behind this rather remarkable arrangement, unique in scholarly publishing, has never been adequately explored; instead, legal commentators have somewhat perversely focused on why Michigan and Northwestern bucked the trend (the answer may have had something to do with the failure of an earlier student-edited joumal at Michigan in 1898 and the financial role of a former Michigan law student in the establishment of the Illinois Law Review; see generally Swygert \& Bruce, supra note 3, at 784-86).

Part of the explanation for student editing may lie in the fact that students initiated the first legal publications at Albany, Columbia, and Harvard, but that may simply beg the question of why most law faculty members were from the outset disinclined to create law reviews for themselves. Law professors might have believed that editing joumals would be good for their students (see supra notes 29-30 and accompanying text), but the same thing might well have been said of students in arts, sciences, and other professional settings. In light of these considerations I would suggest three other possible explanations. First, law professors as a group lacked the time and the financial incentive to run their own joumals. In the late nineteenth and early twentieth centuries, many legal academics were still practicing (see supra note 15 and accompanying text) and spent the majority of their nonteaching hours doing profitable professional work. They arguably saw their students as individuals who would do a job that they could not figuratively or literally afford to do themselves. Second, despite their growing academic aspirations, law professors at the tum of the century were not yet fully assimilated into academic life (some, of course, would suggest that they still are not). For many law professors in this early period, scholarship was not yet so important that its editing and distribution could not be delegated to novices. Third and finally, law professors may have hesitated to edit publications that would, at least ostensibly, compete against commercial legal journals (see supra note 34 ) edited by 
law was amenable to "scientific" study, ${ }^{46}$ thereby proving that a law school belonged in a university.

Of course, it was not altogether accidental that students and professors at the Harvard Law School were the first to realize the law review's potential. James Barr Ames, the Harvard Law Review's principal faculty supporter, was the first of a new breed: the fully academic law professor with minimal practical experience, appointed in the expectation that he would devote his career to teaching and scholarship. ${ }^{47}$ Ames had begun scholarly work (mostly in legal history) soon after joining the Harvard law faculty in 1873 , but prior to 1887 he lacked an obvious outlet for that work in the contemporary legal journals. ${ }^{48}$ His Dean and mentor, Christopher Columbus Langdell, had developed a new pedagogical method-the case method-that he, Ames, and their law students were anxious to celebrate and publicize. ${ }^{49}$ Both Ames and Langdell were operating in a university that, under the leadership of President Charles Eliot, had taken a back seat only to Johns Hopkins in its emphasis on research and publication (and Johns Hopkins, of course, did not have a law school). s $^{50}$ Also facilitating the creation of the law review was the 1886 establishment of the Harvard Law School Alumni Association. The Law School was looking for a means of keeping in touch with graduates already scattered across a wide variety of American, and even foreign, jurisdictions. Its Alumni Association-dominated by well-off Boston and New York lawyers-had access to significant financial resources and was willing to use those resources to advance the Law School's interests. $^{51}$ In these circumstances, the student proposal to create a law

their professional (and in some instances, even academic) colleagues. It was more politic to have students take the appropriate personal and professional risks.

46 For justifications emphasizing the law review's capacity to advance or demonstratc the "scientific" study of law, see Fletcher, supra note 31, at 64 (adding that "in this way the law school ... may be elevated toward the place in public estimation which it is suro ultimately to attain"); Introductory, 1 U. L. Rev. 1 (1893).

47 See Stevens, supra note 8 , at 38 (noting that Ames was appointed professor "for his scholarly and teaching potential").

48 See Swygert \& Bruce, supra note 3, at 773 (referring to Ames's delayed publication of legal historical work until Harvard Law Review's founding).

49 On the students' desire to publicize the faculty and the achievements of the Harvard Law School, see generally John H. Wigmore, The Recent Cases Department, 50 Harv. L. Rev. 862 (1937).

50 On Eliot and the turn to research at Harvard, see generally Hugh Hawkins, Charles W. Eliot, Daniel C. Gilman and the Nurture of American Scholarship, 39 New Eng. Q. 291 (1966) (describing role of faculty scholarship in American universities during late 1800s and early 1900 s).

51 Wigmore, supra note 49 , at $862-63$ (describing fundraising efforts to underwrite publication of new journal). 
review seemed especially attractive. 52 The student editors of the Harvard Law Review explicitly articulated at least some of their school's ambitions for its journal in a note to the first issue:

Our object, primarily, is to set forth the work done in the school with which we are connected, to furnish news of interest to those who have studied law in Cambridge, and to give, if possible, to all who are interested in the subject of legal education, some idea of what is done under the Harvard system of instruction. Yet we are not without hopes that the Review may be serviceable to the profession at large..$^{53}$

Ultimately the attraction of the school-sponsored law journal was such that shortly after the launching of the Harvard Law Review, other journals began to appear under the sponsorship of other law schools. The example and success of Harvard were certainly factors in this trend, ${ }^{54}$ but the rapid proliferation of law reviews in the late nineteenth and early twentieth centuries should not be considered as a mere instance of following the leader. ${ }^{55}$ Some of the same concerns and interests that in the context of improved print technology had apparently urged the Harvard law students and faculty towards journal publication also animated students and legal scholars elsewhere. ${ }^{56}$ In 1891, for example, the editors of the new Yale Law Journal launched their effort with these words:

The graduates of the Yale Law School ... have lacked the esprit de corps, which is necessary for effective unity. The formation of the Alumni Association was a step in the right direction. The Law Jour$\mathrm{nal}$ is intended to be another. It provides a common means of communication between the graduates and the students, and its success should be a mark of the vitality of the school.57

52 Having said this, it is important to note that not all Harvard faculty were initially enthusiastic about the initiative. One of the Review's student founders, Joseph Beale, reported that the members of the faculty displayed "differing degrees of varmth in support offered." Joseph H. Beale, James Barr Ames-His Life and Character, 23 Harv. L Rev. 325,328 (1910).

53 Harvard Notes, supra note 33, at 35.

54 See, e.g., Fletcher, supra note 31, at 65 (1917) (speaking of both Harvard Law Review and its more successful competitors: "We feel the inspiration of their example, we covet the eminence they have earned ...."); Garrard Glenn, Law Reviews-Notes of an Antediluvian, 23 Va. L. Rev. 46, 46 (1936) ("Before the Columbia Law Review was launched [in 1901] ... the Dean of the School was approached, and he consented to the review taking the name Columbia only upon condition that it should adopt the model of Harvard.").

55 Swygert \& Bruce, supra note 3, at 779.

56 See McKelvey, supra note 7, at 870-71 (listing, at length, lavy review objectives and justifications).

57 Editors' Note, supra note 35 , at 30. 
In 1917, the Minnesota Law Review opened its first issue by observing that "[t]he present position of the typical law school, as compared with the medical school, is discreditable to the former; its influence with the profession is not what it ought to be. The law review is one of the means by which the law school may make its influence ... felt ...."

Over time, the focus of justifications for new law reviews changed subtly as law schools gained prestige (making bold declarations of institutional ambition superfluous), alumni relations came to be fostered through other channels (making that purpose of law review publication less important), and not publishing a law review became more remarkable than publishing one (making justifications as a whole less necessary, or at least less lengthy). Functionality, however, continued to be seen as the key to a review's potential success. As the editors of the George Washington Law Review explained in their first issue, produced forty-five years after Harvard's: "Publication of a law review by any school is justified by the additional contributions to legal literature which it stimulates and the opportunities for better training of students which it affords." 59

This brief history of the initial development and popularization of the law review suggests that the law review was very much the product of its time ${ }^{60}-$ in particular, the product of a conjunction of contemporary academic circumstances and then-current technological advances. Insofar as it had emerged in response to perceived goals, however, the law review was potentially vulnerable to criticism as it tried to fulfill those goals and as those goals evolved. The next section of this Article traces the course that criticism of the law review has taken over the years, investigates why various criticisms arose when they did, and examines the structural and substantive reforms that have attempted to preserve or advance the law review's position in the ever-changing American legal academy.

\section{II}

\section{The Critical Tradition}

Criticizing the law review is a time-honored legal tradition. Almost from the outset of the institution, dissident law professors, practitioners, judges, and occasionally even law students have complained

58 Fletcher, supra note 31 , at 64 .

59 Editor's Note, 1 Geo. Wash. L. Rev. 92 (1932).

60 See Roger Cramton, The Most Remarkable Institution: The American Law Review, 36 J. Legal Educ. 1, 4 (1986) (observing that "the times were ripe; and if the developments had not come about at Harvard in 1887 they would probably have at Columbia or Pennsylvania or elsewhere a few years later"). 
about its form, its content, and its operation. ${ }^{61}$ The precise nature of the criticisms has varied over time, largely in response to developments in American legal education and the larger American legal and social environment which have affected the needs, attitudes, and expectations of the law review's constituencies. Commentators have repeatedly remarked on the law review's apparent ability to resist criticism, ${ }^{62}$ but in fact the institution has responded to several challenges since its inception. Its fundamental problem today is not that it has not changed, but that it has not changed enough.

Criticisms of the law review have historically tended to come in waves, each wave larger and more powerful than the last. The first, weakest, and most diffuse wave of criticism lasted roughly from 1905 to 1940 , coinciding with much of the law review's initial period of development and popularization. To some extent, the first wave of criticism was a reaction against the relatively rapid proliferation of schoolsponsored legal journals in the early decades of the twentieth century. The numbers speak for themselves: in 1900, there were seven law reviews; 63 in 1928 , there were thirty-three; 64 in 1937 , there were fifty. ${ }^{65}$ As early as 1906, the faculty editors of the new state-oriented Illinois Law Review expressed the feeling that the "field for law reviews of a general character is already overcrowded." 66 Restraint, reorientation, and specialization were said to be in order: in 1927, Illinois's Albert Kocourek even went so far as to suggest that "the Harvard Law Review might become what is consistent with its traditions, a journal of legal history; the Yale Law Journal might become a journal of jurisprudence; and the Columbia Law Review might become a journal of commercial law."67

The first wave of law review criticism was also a by-product of the gradual standardization of the law review format which had come with the growing popularity and power of the genre. After a brief period of experimentation from the late 1880s through 1900-during which the law reviews carried such things as school news and lecture notes-

61 See infra notes 67-197 and accompanying text.

62 See generally Geoffrey Preckshot, All Hail Emperor Law Review: Criticism of the Law Review System and Its Success at Provoking Change, 55 Mo. L. Rev. 1005 (1990).

63 See Frederick C. Hicks, Materials and Methods of Legal Research 207 (3d ed. 1942) (listing all American law school periodicals existing in 1942 with initial years of publication). This statistic does not, however, reflect all of the 19 attempts made to create schoolsponsored law reviews up to the tum of the century; for a variety of reasons, the majority of these early initiatives failed. See id. at 206.

64 Barbara H. Cane, Comment, The Role of Law Review in Legal Education, $31 \mathrm{~J}$. Legal Educ. 215, 220 n.32 (1981).

65 McKelvey, supra note 7, at 868.

66 Editorial Notes, 1 IIl. L. Rev. 39, 39 (1906).

67 A.K., Editorial Note, The Law Review, 21 Ill. L. Rev. 147, 153 (1926). 
most fell into a set (and, to us, more familiar) structure: leading articles, student-written case comments, and book reviews. They also settled into a definable style: careful, plodding, and rather heavily footnoted. These developments did not sit well with everyone in the legal professoriate; the dissatisfaction of critics only increased as the reviews appeared to become more hidebound over time.

In 1936, as the fiftieth anniversary of the Harvard Law Review drew near, Yale's Fred Rodell made it plain that he had had enough. In his Virginia Law Review article Goodbye to Law Reviews ${ }^{68}$ (which in later years would ultimately, and perhaps ironically, become the most-cited law review article on law reviews) he declared that there were two problems with legal writing in general and law review writing in particular: "One is its style. The other is its content."69 Armed with a rapier wit and a poison pen, Rodell decried the conservatism of editors and the stultifying, humorless sameness of the law review format they favored. ${ }^{70} \mathrm{He}$ bewailed what he regarded as the specious and largely superfluous business of footnotes. More accurately than some of his colleagues, friends, and students might have wished, he attributed these and other problems to the law review's nature as a product of the collective self-interest of career-conscious professors, job-seeking students, and idea-hoarding law firms. ${ }^{71}$ Rodell's disgust with the existing system was such that he doubted whether he would ever write a law review article again. ${ }^{72}$

Student editorial control of law reviews was another early cause of concern, especially after a number of law schools that had originally founded faculty-edited journals either gave up their experiments (e.g., Iowa, in 1901) or radically reduced the degree of faculty supervision (e.g., Wisconsin, during the late 1920s). ${ }^{73}$ Speaking from the bench of the United States Supreme Court in 1911, former commercial law journal editor Oliver Wendell Holmes, Jr. dismissed law reviews in

68 Fred Rodell, Goodbye to Law Reviews, 23 Va. L. Rev. 38 (1936).

69 Id. at 38.

70 Id. at 44 . Rodell was in good company. One of the original student founders of the Harvard Law Review, John Wigmore, admitted the same year: "I sometimes wonder if this journal-type is not becoming staled. Has mass-organization resulted in too much standardization?" Wigmore, supra note 49 , at 867 .

71 Rodell, supra note 68 , at $44-45$.

72 Id. at 38.

73 The Wisconsin Law Review was established in 1920 as a faculty-run journal; by 1930 . it had become "a more autonomous, student-run organization with less control and influence being exerted by the faculty." The Wisconsin Law Review: Fifty Years of Proud Tradition, 1970 Wis. L. Rev. 973, 973. Students became the sole editors in 1935, although a faculty advisor was retained. Id. at 974 . 
general as the "work of boys." "74 In 1927, the faculty editor of the Illinois Law Review contended that, "[w]hile preparation of case notes by students is excellent training, and while the researches of law students are valuable in gathering material, in classifying the trend of decisions, and in presenting points of view ... the bar is entitled to more than that."75 Iowa law professor Clarence Updegraff explicitly opined in 1929: "[T] he criticism and revision of leading articles, at least in the majority of schools, should be a faculty matter. The best of law students will scarcely be sufficiently well prepared to decide in a close case whether a submitted article should be published or not."76

Finally, some of the criticisms of law reviews made in the 1930s in particular were directly or indirectly induced by the rise of legal realism, a broad school of jurisprudence that used social science concepts to challenge traditional doctrinal styles of legal analysis.77 The realist attack on "classical" legal thought became an attack on the law reviews which had been born of, and in turn had helped to nurture, narrow case-based legal theory. Fred Rodell's 1936 critique of law reviews was certainly sharpened by his realism. ${ }^{78}$ Duke's David Cavers, although not a realist himself, nonetheless reflected realism's impact when he observed in the same year that law reviews had a restricted "plane of discussion," having confined themselves to the concerns of courts and lawyers without reference to the social context of legal problems. ${ }^{79}$

Largely because of the somewhat spotty and disjointed nature of these early reproaches of the law reviews, not to mention the paeans, apologias, and ripostes which more than counterbalanced them, ${ }^{80}$ the

74 Charles E. Hughes, Foreword, 50 Yale L.J. 737, 737 (1941) (quoting Holmes from memory of some "thirty years ago [when] he admonished counsel who had the temerity to refer to [law review notes] in argument"). From 1870-1873, Holmes had served as Editor of the American Law Review.

75 A.K., supra note 67, at 149.

76 Clarence M. Updegraff, Management of Law School Reviews, 3 U. Cin. L. Rev. 115. 119-20 (1929).

77 See generally American Legal Realism (William W. Fisher III et al. eds., 1993).

78 On Rodell's realism, see Neil Duxbury, In the Twilight of Legal Realism: Fred Rodell and the Limits of Legal Critique, 11 Oxford J. Legal Stud. 354 (1991).

79 Cavers, supra note 43 , at 6-7.

80 In 1913, for example, the editors of the Cornell Law Quarterly responded to the Illinois Law Journal's earlier criticisms of the genre:

It is seriously to be questioned whether the mere fact of the multiplication of periodicals in any field of serious endeavor is evidence of waste. One may reasonably assert that the extraordinary number of scientific and technical reviews published in Germany (for example, a dozen or more devoted to entomology) is rather the natural and inevitable expression of intense, varied and widespread intellectual activity.

Woodruff, supra note 29, at 27. Rather more grandiosely, Karl Llewellyn later argued, 
first wave of criticism had only slight impact on the existing law review structure. After the inauguration of the Illinois Law Review in 1906, an increasing number of state-based law reviews (e.g. the California Law Review (1912) and the Wisconsin Law Review (1920)) began publication in the hopes of cutting niches for themselves in the general literature. In 1925, the University of Chicago, the University of Illinois, and Northwestern University tried to avoid duplication of effort (not to mention product) by sharing sponsorship of the same Illinois Law Review which had initially been published under the auspices of Northwestern alone. ${ }^{81}$ A couple of law reviews specializing in particular subjects appeared in the 1930s (e.g., the George Washington Law Review, specializing in federal public law, and the Journal of Air Law, edited out of Northwestern University and the University of Southern California law schools). In 1933, David Cavers and the Duke Law School launched the faculty-edited (if still student-staffed) journal Law and Contemporary Problems, an overtly interdisciplinary publication which pioneered a "symposium" format designed to foster subject-specialization and thereby to reduce redundancy across reviews. ${ }^{82}$

None of these reforms was particularly fundamental or successful, however. The state-based law reviews were little more than smaller versions of the general model; many of them actually evolved into general publications in later years. ${ }^{83}$ The joint editorial arrangement of the Illinois Law Review collapsed in 1932, when Northwestern law students took it over. ${ }^{84}$ Despite some articulate arguments made on their behalf, ${ }^{85}$ the number of specialized law reviews remained small through the 1940s, largely because of the limited scope for publicity

[The] law review is . . . a thing American. Here is a thing Americans may well be proud of. There is not so far as I know in the world an academic faculty which pins its reputation before the public upon the work of undergraduate students-there is none, that is, except in the American law reviews. Such an institution it is a privilege to serve. Such an institution it is an honor to belong to.

K.N. Llewellyn, The Bramble Bush 105 (Oceana Publications 1951) (1930); see also Frederick E. Crane, Law School Reviews and the Courts, 4 Fordham L. Rev. 1, 1-3 (1935) (discussing reliance of judges and practicing lawyers on law school journals); Douglas B. Maggs, Concerning the Extent to Which the Law Review Contributes to the Development of the Law, 3 S. Cal. L. Rev. 181, 190 (1930) (concluding that "each law school not now publishing a law review should be encouraged to institute one").

81 For a brief description of the experiment and its early results, see A.K., supra note 67 , at 148.

82 See Foreword, 1 Law \& Contemp. Probs. 1 (1933) (stating these goals).

83 A.K., supra note 67 , at 150 .

84 Editorial, 27 Ill. L. Rev. 290 (1932).

85 See, e.g., Cavers, supra note 43, at 11-19 (proposing that specialized reviews would extend range of legal scholarship and suggesting subject areas and possible format). 
that they afforded to their sponsoring schools. For a variety of reasons (not least of which was the legal academy's incipient retreat from realism ${ }^{86}$ the journal Law and Contemporary Problems found it difficult to meet its own interdisciplinary aspirations let alone inspire other reviews to adopt a similar course. The symposium format was occasionally adopted by a few law reviews, ${ }^{87}$ but was quickly recognized, even by its inventor, as being "not well-suited for general use. It compels a shifting of the field of inquiry with each issue ... [and] cannot provide an always-available outlet for the writer who is working on a topic which ... does not happen to coincide with the current editorial program." 88

The lack of significant or successful response to the first wave of law review criticism facilitated the build-up of a second wave. Perhaps predictably, this struck the law reviews in the 1950 s and early 1960s after a brief hiatus which had lasted through the war and immediate postwar periods. Many second-wave complaints were obviously the result of ongoing frustration. In 1952, for instance, Illinois's John Cribbet complained that the law reviews were too similar to one another; he called for "experimentation in every phase of the review from the cover and format to the type of note and case comment." 89 The next year, Judge Stanley Fuld of the New York Court of Appeals chided law reviews for their plethora of footnotes and their duplication of effort.90 Emory's Arthur S. Miller lamented the "monotonous uniformity" of the journals in 1955, and pointedly deplored the tendency of student note writers in different reviews to comment on the same cases, with the result that in some instances a single case was noted eighteen or nineteen times.91 In 1962, twenty-five years after his first broadside against law reviews, Fred Rodell himself returned to give them a second skewering. Asserting that a "quarter century has wrought no revolution,"92 he repeated his original critique and went on to suggest that the style of law review articles had deterio-

86 See generally G. Edward White, From Realism to Critical Legal Studies: A Truncated Intellectual History, 40 Sw. L.J. 819 (1986).

87 See, e.g., Augustus N. Hand, Foreword, 33 Iowa L. Rev. 193 (1948) (introducing symposium issue on State Administrative Procedure); Labor Relations and the Law: A Symposium, 14 U. Chi. L. Rev. 331 (1947). The University of Illinois Law Forum (a stateoriented law review) began publishing symposium issues on a regular basis in 1950.

88 Cavers, supra note 43 , at $11-12$.

89 John E. Cribbet, Experimentation in the Law Reviews, 5 J. Legal Educ. 72, 81 (1952).

90 Stanley H. Fuld, A Judge Looks at the Law Review, 28 N.Y.U. L. Rev. 913, 919-20 (1953).

91 Arthur S. Miller, A Modest Proposal for Changing Law Review Formats, 8 J. Legal Educ. 89, 89, 91 (1955).

92 Fred Rodell, Goodbye to Law Reviews-Revisited, 48 Va. L. Rev. 279, 286 (1962). 
rated even beyond the sad state in which he had found it in the late 1930s. ${ }^{93}$

Frustration with the lack of fundamental change was not, however, the only factor behind the second wave of law review criticism. By the 1950s, the American legal academy had changed in ways that presented not only new opportunities, but new problems. For one thing, there were significantly more law reviews (76 in 1952, up from 50 in 1937). ${ }^{94}$ In this context Chicago's Alan Mewett could and did repeat the old saw about "too many law reviews," giving it a new spin by suggesting that the multitude of scholarly outlets made articles in any one subject area hard to find, even with the aid of the Index to Legal Periodicals. 95 Mewett argued that marginal law reviews which had to solicit articles or which had difficulty in meeting deadlines deserved to be shut down; 96 he advised authors to accelerate this process by boycotting these journals in the first place. ${ }^{97}$

Increased pressure to research and publish provided another reason for American law professors to focus more critical attention on law reviews in the 1950 s and early 1960s. A certain pressure or at least incentive to publish had of course existed in legal academia since the inception of law reviews in the late nineteenth century, but only after 1950 did the push towards publication become generally significant. To some extent, law schools in these years caught up with other university schools and departments which in the early 1940s had fallen victim to the "publish or perish" approach to tenure and promotion. 98 In part also, legal research became more important because the continued multiplication of law reviews made publication of scholarship more achievable and even made frequent publication necessary to the survival of some of the lesser reviews. ${ }^{99}$ In 1957, Wisconsin's Willard Hurst called for more financial and personal resources to support law professors' research efforts. ${ }^{100}$ In 1959, the Association of American

93 See Rodell, supra note 68 , at $286-90$.

94 See Cribbet, supra note 89, at 73; McKelvey, supra note 7, at 868 .

95 Alan W. Mewett, Reviewing the Law Reviews, 8 J. Legal Educ. 188, $188-89$ (1955).

96 Id. at 189.

97 Id. at 191; see also John G. Hervey, There's Still Room for Improvement, 9 J. Legal Educ. 149, 151 (1956).

98 The phrase "publish or perish" was apparently coined by Logan Wilson in his classic study, The Academic Man: A Study in the Sociology of a Profession 197 (1942) ("The prevailing pragmatism forced upon the academic group is that one must write something and get it into print. Situation imperatives dictate a 'publish or perish' credo within the ranks.").

99 See generally Stevens, supra note 8 , at 271 (reporting that "[t]he emphasis of law professors on article writing flourished in the 1950s as the number of law reviews grew").

$100 \mathrm{~J}$. Willard Hurst, Research Responsibilities of University Law Schools, $10 \mathrm{~J}$. Legal Educ. 147, 153-54 (1957). 
Law Schools (AALS) went so far as to adopt a formal "[R]esearch Standard," declaring for the first time that "[f]aculty members have an important responsibility to advance as well as to transmit ordered knowledge."101

Renewed criticism of the law review system was also prompted by the fact that by the 1950s and 1960s almost all the law reviews had become formally independent from law faculties. At the University of Michigan, for instance, faculty control had begun to ebb in the early 1940s; by 1952, students had taken over most editorial responsibilities, with faculty serving primarily in an advisory capacity. ${ }^{102}$ Developments like this led Alan Mewett to declare that law students had "no place on a law review" as either editors or authors. ${ }^{103}$ Columbia's Arthur Nussbaum conceded that student editing might have been a good idea in an earlier, simpler, more doctrinal time,

[but] the situation has changed .... Such matters as, say, labor law, taxation law, corporation and trust law, public control of business, etc., are steadily developing new and intricate problems; legal philosophy is being paid far more attention than in the past; the expanding relationship among the countries of Western civilization, and this country's leading role within that orbit, render necessary in many more cases than ever before the investigation of international and foreign law. Students may not have acquired the knowledge and maturity to handle those trends adequately as independent editors. ${ }^{104}$

Finally, at least one second-wave complaint about law reviews was prompted by a new egalitarianism which gained strength both inside and outside law schools in the 1950s and early 1960s. A number of commentators openly wondered why, if law review experience was so pedagogically and professionally valuable, it should be limited to that small number of law school students who received high first-year grades. The question appears to have been raised for the first time in the mid-1940s, ${ }^{105}$ but in the 1950 s and early 1960 s it was raised again. As law schools in these years adopted much more selective admissions policies, ${ }^{106}$ singling out some students over others became more prob-

101 Stanley E. Harper, Jr., Caution, Research Ahead, 13 J. Legal Educ. 411, 411 n.2 (1961) (quoting Association of Am. Law Sch., Proceedings 19495 (1959)).

102 Stason, supra note 28 , at 1137.

103 Mewett, supra note 95, at 190.

104 Arthur Nussbaum, Some Remarks About the Position of the Student-Editors of the Law Review, 7 J. Legal Educ. 381, 381 (1955).

105 See, e.g., Harold Marsh, Jr., The Law Review and the Law School: Some Reflections About Legal Education, 42 Ill. L. Rev. 424, 433-34 (1947); Howard C. Westwood, The Law Review Should Become the Law School, 31 Va. L. Rev. 913 (1945).

105 See Stevens, supra note 8, at 221 n.38. Berkeley, for instance, accepted $70 \%$ of its applicants in 1954, but only $34 \%$ in 1968 . Id. 
lematic. Judge Stanley Fuld found it "a pity that many more students cannot share in [the law review], that some rotating system has not been devised to allow for a broader participation in review work."107 In 1956, the Dean of Northwestern, Harold Havighurst, suggested that this could be done by allowing for law review publication of some of the better student papers being produced in new seminar-style law school courses. ${ }^{108}$

Partly because of its greater intensity, the second wave of law review criticisms ultimately had more impact than had the first wave. Certainly law reviews still had more than their share of plaudits and unrepentant proponents through this period, ${ }^{109}$ but starting in the 1950 s and continuing into the 1970 s, change was in the air in law schools and law review offices across the country. Like the criticisms, some of the changes were extensions of earlier initiatives rather than entirely new departures. Symposium issues, for instance, continued to gain in popularity, as did specialist (mostly faculty-edited) journals such as the American Journal of Legal History (1957), the Journal of Law and Economics (1958), the Supreme Court Review (1960), the Journal of Urban Law (1966),110 and the Journal of Legal Studies (1972). Other changes were more novel. In the 1960s and 1970s, law review membership was increasingly offered to students who won

107 Fuld, supra note 90, at 917; see also Roger J. Traynor, To the Right Honorable Law Reviews, 10 UCLA L. Rev. 3, 4 (1962) (calling for extension of law review training "to as many students as are willing and able to benefit therefrom").

108 Harold C. Havighurst, Law Reviews and Legal Education, 51 Nw. U. L. Rev. 22, $25-$ 26 (1956); see also Roy Moreland, Unfair Domination of Law Reviews, 12 J. Legal Educ. 424 (1960) (calling for publication of student papers by non-law review members so as to extend legal research training to more law students).

109 See, e.g., Kenneth F. Burgess, Law Reviews and the Practicing Lawyer, 51 Nw. U. L. Rev. 10, 14 (1956) (declaring that "[n]o convincing reason exists, from the standpoint of the practicing lawyer, for altering the established format of the law review"); Havighurst, supra no:e 108, at 24 (meeting criticism that too many law reviews were being produced for too few readers by noting that "[w]hereas most periodicals are published primarily in order that they may be read, the law reviews are published primarily in order that they may be written"); Arthur H. Kahn, Comment, Some Additional Remarks about the Position of the Student-Editors of the Law Review, 9 J. Legal Educ. 73 (1956) (defending student editorial control); William M. Moldoff, Reviewing the Law Reviews: An Answer, 8 J. Legal Educ. 497 (1956) (responding to Mewett); Traynor, supra note 107, at 8 (responding to critics denigrating law review as product of students: "They pay no heed to the evidence that the average apprentice in an American law school has long since reached the age of discretion and that he is no ordinary student."); Earl Warren, Message of Greeting to the U.C.L.A. Law Review, 1 UCLA L. Rev. 1, 1 (1953) ("The American law review has properly been called the most remarkable institution of the law school world.").

110 This journal actually originated as the University of Detroit Law Journal; it represented one of the few instances of a law school deciding to replace its general journal with a specialist law review. The practice of student editorial control survived the transition. See Introduction, 44 J. Urb. L. 1, 1 (1966). 
writing competitions as well as to those with high first-year grades. ${ }^{111}$ Some law reviews also experimented with new formats: the Wisconsin Law Review, for example, launched a "Commentary" section affording authors "an opportunity to discuss and evaluate issues important to the profession which can not be dealt with comfortably in the format of a traditional leading article."112 Much to the delight of John Cribbet, the bright-colored cover even made its debut on the front of the Stanford Law Review. ${ }^{113}$

Again, however, the changes were less than revolutionary. The numbers of law reviews continued to increase. Occasional experiments notwithstanding, the traditional structure of law review issues survived mostly intact. The practice of student-editing continued to predominate, limiting the feasibility of symposia and specialist journals which almost by definition required faculty supervision. Thanks to writing competitions, a greater number and greater range of students made law review, but an internal hierarchy soon developed which favored individuals who had "graded on."114 For these and other reasons, discontent with law reviews continued to simmer through the early 1980 s. ${ }^{115}$

In the mid-1980s, that simmering discontent exploded into a third wave (or, perhaps more accurately, a tsunami, i.e., tidal wave) of criticism which has not only been sustained to date but has in fact gained in size and intensity. More articles assailing law reviews, containing more pages of criticism and more vitriolic language have appeared in the last ten years than had appeared in the entire corpus of law review literature prior to 1985 . A number have been written by highly

111 See, e.g., James R. Clark, The Wisconsin Law Review in Today's Legal and Educational Environment, 1970 Wis. L. Rev. 983, 987 (describing Wisconsin Law Review's program allowing students to participate as editors pursuant to writing competition).

112 The Wisconsin Law Review: Fifty Years of Proud Tradition, supra note 73, at 974.

113 Cribbet, supra note 89 , at 81 .

114 See Cane, supra note 64, at 222 ("[N]ot all means of achieving [law review] membership are considered equally prestigious.").

115 See, e.g., Clark, supra note 111, at 983-84 (criticizing lack of editorial continuity in student-edited law reviews); John F.T. Murray, Publish and Perish-By Suffocation, 27 J. Legal Educ. 566 (1975) (criticizing repetition and marginal quality of most law review writing produced under pressures of "publish or perish"); Louis B. Schwartz, Civilizing the Law Review, 20 J. Legal Educ. 63 (1967) (criticizing narrow, technical scope of law reviews); Edd D. Wheeler, The Bottom Lines: Fifty Years of Legal Footnoting in Review, 72 Law Libr. J. 245 (1979) (criticizing radical lengthening, if not necessarily radical proliferation, of law review footnotes since 1928); The Law Review-Is It Meeting the Needs of the Legal Community?, 44 Denv. L.J. 426 (1967) (presenting results of one-year Denver Lav Journal survey of law reviews' content and its evaluation by judges, attomeys, and lav professors). 
respected, established scholars, most notably Roger Cramton, ${ }^{116}$ Richard Posner, ${ }^{117}$ and James Lindgren. ${ }^{118}$ In the last two years alone, the law review system has been the focus of two law review symposium issues"19 and one extended "Exchange";,120 in June 1995, the growing controversy over the operation and reform of law reviews even drew the attention of America's principal academic weekly, the Chronicle of Higher Education, which devoted a cover story to it. ${ }^{121}$

Many factors have contributed to this latest critical onslaught. First and most obviously, the absolute number of law reviews has skyrocketed in the past thirty years. It is not so much that certain law schools have decided to publish a law review for the first timerather, many schools with well-established law reviews have for reasons internal (e.g., extending student participation) and external (e.g., the development of subfields which "flagship" reviews were unable or unwilling to cover) ${ }^{122}$ begun to publish one or more supplementary journals focusing on particular subject areas. The "elite" law schools have inaugurated numerous new publications: in the last three decades Harvard has started nine that survive to this day (in addition to the Harvard Law Review), ${ }^{123}$ Berkeley has started

116 See, e.g., Cramton, supra note 60 (describing and criticizing student-edited law reviews).

117 See, e.g., Richard A. Posner, The Future of the Student-Edited Law Review, 47 Stan. L. Rev. 1131, 1133 (1995) (pointing to law reviews' failure and inability to adapt to changing nature of American law and American legal scholarship).

118 See, e.g., James Lindgren, An Author's Manifesto, 61 U. Chi. L. Rev. 527,531 (1994) [hereinafter Lindgren, Manifesto] (arguing that student editors are "grossly" unsuited for jobs facing them); James Lindgren, Fear of Writing, 78 Cal. L. Rev. 1677, 1681-94 (1990) [hereinafter Lindgren, Fear of Writing] (criticizing rules in Texas Law Review Manual of Style as wrong and misleading); James Lindgren, Reforming the American Law Review, 47 Stan. L. Rev. 1123, 1124-28 (1995) [hereinafter Lindgren, Reforming] (explaining that American law review is in transition and prescribing four revised models for student-edited law reviews).

119 See Symposium on Law Review Editing: The Struggle Between Author and Editor Over Control of the Text, 70 Chi.-Kent L. Rev. 71 (1994); Special Issue: Law Review Conference, 47 Stan. L. Rev. 1147 (1995).

120 See Exchange, 61 U. Chi. L. Rev. 527 (1994) (including Lindgren, Manifesto, supra note 118, at 527, Wendy J. Gordon, Counter-Manifesto: Student-Edited Reviews and the Intellectual Properties of Scholarship, at 541, and The Articles Editors, A Response, at 553).

121 See Christopher Shea, Students v. Professors: Law-Review Debate Heats Up as Student Editors Clash with Faculty Authors, Chron. Higher Educ., June 2, 1995, at A33; see also Rosa Ehrenreich, Look Who's Editing, Lingua Franca, Jan./Feb. 1996, at 58.

122 For example, feminist jurisprudence and women's legal issues, environmental law, civil rights law, international law, tax law, entertainment law, comparative law, and computers and law.

123 The Harvard BlackLetter Journal, the Harvard Civil Rights-Civil Liberties Law Review, the Harvard Environmental Law Review, the Harvard Human Rights Journal, the Harvard International Law Journal, the Harvard Journal of Law and Public Policy, the Harvard Journal of Law and Technology, the Harvard Journal on Legislation, and the 
eight, ${ }^{124}$ Columbia and Georgetown have started seven, ${ }^{125}$ and Yale and New York University have started five. ${ }^{26}$ Other "lesser" law schools have also been very active: Tulane, for instance, now boasts six law reviews, Notre Dame boasts five, and Temple boasts four. ${ }^{127}$ The consequences of these trends for law review publishing as a whole have been predictable. In 1966, there were 102 school-affiliated law reviews. ${ }^{128}$ In 1981, there were more than 180.129 In 1990, there were 307.130 In 1995, there were (by one count) 382.131 This unprecedented proliferation of school-sponsored legal periodicals has led to renewed complaints not only about sheer volume, ${ }^{132}$ but also about the low or

Harvard Women's Law Journal. Law Sch. Admission Council, The Official Guide to U.S. Law Schools 179 (1995). As of this writing, Harvard is about to start yet another journal, the Harvard Negotiation Law Review. Everyone's an Editor, Student Law., Nov. 1995, at 5.

124 The African-American Law and Policy Report, the Asian Law Journal, the Berkeley Journal of Employment and Labor Law, the Berkeley Women's Law Journal, the Ecology' Law Quarterly, the High Technology Law Journal, the International Tax and Business Lawyer, and La Raza Law Journal. Law Sch. Admission Council, supra note 123, at 92.

125 The Columbia reviews include the Columbia Business Law Review, the Columbia Human Rights Law Review, the Columbia Journal of Environmental Law, the Columbia Journal of Gender and Law, the Columbia Journal of Law and Social Problems, the Columbia Journal of Transnational Law, and the Columbia-VLA Joumal of Law \& the Arts. The Georgetown reviews include the American Criminal Law Review, Georgetown Immigration Law Journal, the Georgetown Journal of Legal Ethics, the Georgetovn Journal on Fighting Poverty, the Georgetown International Environmental Law Review, Law and Policy in International Business, and the Tax Lawyer. Id. at 167.

126 Yale journals include the Yale Journal of International Law, the Yale Journal of Law and Feminism, the Yale Journal of Law and the Humanities, the Yale Joumal on Regulation, and the Yale Law and Policy Review. New York University publishes the Annual Survey of American Law, the New York University Environmental Law Journal, the New York University Joumal of International Law and Politics, the New York University Review of Law \& Social Change, and the Tax Law Review (faculty-run). See id. at 257 (listing student-run journals only).

127 Id. at $369,272-73,351$.

128 Cane, supra note 64 , at 220 n.32.

129 Id. at 215.

130 Preckshot, supra note 62, at 1009 n.25 (1990) (citing Index to Legal Periodicals (Supp. Oct. 1989)).

131 This figure was obtained by counting those law journals in the Index to Legal Periodicals which either carry a law school's name in their titles or list a law school as an editorial address. Index to Legal Periodicals (Supp. June 1995). It may be a low estimate, however. the information on individual law schools in The Official Guide to U.S. Law Schools, published by the Law School Admissions Council, collectively suggests a figure closer to (or, given gaps in its coverage, even above) 413 . See Law Sch. Admission Council, supra note 123, passim.

132 One law dean has offered the following tongue-in-cheek proposal as a means of "solving" the problem: "Law schools should enter into a non-proliferation treaty on law reviews. No new reviews, gradual destruction of existing stockpiles until all are destroyed." Roger I. Abrams, This is Not an Article, or Scholarship: The Greek Salad, 13 Nova L. Rev. 33, 37 (1988). 
at best uneven quality of many law reviews. ${ }^{133}$ Even more significantly, it has prompted concern about the high cost to law schools and law school libraries of fueling and sustaining such an elaborate system at a time when an increasing number of universities and law schools are operating under budget constraints. ${ }^{134}$

Second and most significantly, the pressure on legal academics to publish, to publish more, and to publish more frequently has become much greater in the last ten to twenty years. We have seen that this pressure had already increased in the 1950s and early 1960s. In the mid-1970s, however, scholarship took on unprecedented importance as a measure of academic worth. As competition for good students ${ }^{135}$ and good professors increased, and as legal educators took an interdisciplinary turn which brought them under the influence of more research-oriented arts and humanities departments, ${ }^{136}$ law schools increasingly required that members of their faculties produce a substantial quantity of respectable written work-generally, two or three law review articles to obtain tenure, and several more to obtain promotion. Concomitantly, the number of law professors denied tenure because of poor or inadequate legal scholarship rose dramatically: in 1968-1973, for instance, only eight tenure denials were substantially attributable to faculty dissatisfaction with candidates' scholarship; in 1973-1978, scholarship considerations played a role in twenty-four tenure denials. ${ }^{137}$ Since the early 1980 s, scholarship has become even more central in the tenure and promotion process. ${ }^{138}$ This has meant that law review editors, acting in their capacities as primary gatekeepers and streamers of legal scholarship, have incidentally but inevitably

133 See, e.g., Kenneth Lasson, Scholarship Amok: Excesses in the Pursuit of Truth and Tenure, 103 Harv. L. Rev. 926, 928 (1990) ("Slops fill the law reviews. Simply put, there are too many of them.").

134 On this problem in academia as a whole, see Deana L. Astle, The Scholarly Journal: Whence or Wither, $15 \mathrm{~J}$. Acad. Librarianship 151 (1989). On law school budget and financing problems in particular, see, e.g., Richard Reuben, State Law Schools Squeezed for Cash, A.B.A. J., Apr. 1994, at 32.

135 See Arthur D. Austin, Footnotes as Product Differentiation, 40 Vand. L. Rev. 1131, 1138 (1987) ("Looking for a way to ... compete successfully for bright students, ambitious schools followed academic tradition by giving first priority to research and scholarship. ... 'Publish or perish' descended on law schools with a vengeance.").

136 See infra notes $177-80$ and accompanying text.

137 Elyce H. Zenoff \& Lizabeth A. Moody, Law Faculty Attrition: Are We Doing Something Wrong?, 36 J. Legal Educ. 209, 220 (1986) (citing Association of Am. Law Sch., Tenure Practices Survey-Preliminary Report 12 (Oct. 3, 1978)).

138 See Graham C. Lilly, Law Schools Without Lawyers? Winds of Change in Legal Education, 81 Va. L. Rev. 1421, 1437 (1995) (referring to "mounting pressure on young academics, particularly untenured ones, to research and publish"); Zenoff \& Moody, supra note 137, at 220-21 (discussing "recent emphasis on scholarship" in tenure process). 
acquired a critical degree of control over law professors' careers and reputations.

In this predicament, law professors have understandably become more critical of law review operations in general. Many negative comments have focused on how articles are selected for publication. The concern here is not so much that dubious and/or arbitrary student decisionmaking prevents any given article from being published somewhere, but that it may compromise an article's chances of getting published in a "leading" law review where it would more likely be noticed ${ }^{139}$ and appreciated. ${ }^{140}$ Professors have alleged that student editors are incompetent to judge academic contributions to an evermore-complex field, 141 and often rely on irrelevant "secondary" criteria, such as the reputation and/or background of the author, ${ }^{142}$ the prestige of his or her institution, ${ }^{143}$ or the number of prominent names the author can drop in an "acknowledgements" footnote. 144 They have asserted that students are inherently conservative ${ }^{145}$ (or, alternatively, faddish) ${ }^{146}$ in their publication choices, preferring the familiar to the truly original. They have alleged that students at elite law schools in particular ${ }^{147}$ are unduly biased in favor of faculty at their

139 On the tendency of most law professors, lawyers, and judges to cite, and more generally read, only a very few law reviews (essentially those from the "elite" schools), see Olavi Maru, Measuring the Impact of Legal Periodicals, 1976 Am. B. Found. Res. J. 227, 232-42.

140 Some law faculties actually require that their junior members publish in a prescribed number of "acceptable" (read "elite" or "high-profile") law reviews. Michael Vitiello, Journal Wars, 22 St. Mary's L.J. 927, 929 (1991). Even among those faculties where no such formal requirement exists, article placement is often taken as a proxy for the quality of the piece. Id. at 936.

141 See, e.g., Cramton, supra note 60, at 7 (noting that modern legal scholarship has demolished effectiveness of student editing); Lindgren, Manifesto, supra note 118 , at 528 (pointing out that law review staffs are greatly disadvantaged because students are ignorant, immature, inexperienced, and have inadequate incentives); Posner, supra note 117, at 1132 (explaining that student editors, who are often young and work part-time, do not comprehend the scholarly enterprise they manage).

142 See, e.g., Banks McDowell, The Audiences for Legal Scholarship, $40 \mathrm{~J}$. Legal Educ. 261, 269 (1990).

143 Lindgren, Manifesto, supra note 118, at 530.

144 See Arthur D. Austin, The "Custom of Vetting" as a Substitute for Peer Review, 32 Ariz L. Rev. 1, 5-7 (1989).

145 See, e.g., Cramton, supra note 60, at 8 (alleging that student editors discourage innovation); Lindgren, Manifesto, supra note 118, at 533 (observing two most frequently selected topic areas for articles are constitutional law and corporate lav); Laura F. Rothstein \& Mark A. Rothstein, Law Reviews Suffer from Lack of Peer Review, Legal Times, Jan. 6, 1986 , at 10 (arguing that similar pieces are frequently chosen for publication).

146 Carl Tobias, Manuscript Selection Anti-Manifesto, 80 Comell L. Rev. 529, 530 (1995).

147 See, e.g., Ira M. Ellman, Comparison of Law Faculty Production in Leading Law Reviews, 33 J. Legal Educ. 681, 685 (1983) (citing editors of Virginia Law Review for filling 1323 of 2794 pages with their own faculty's material over two and one-half year period). 
own institutions. ${ }^{148}$ They have expressed resentment at having more or less to beg the editors of higher-ranking reviews for "expedited reads" of an article after it has been accepted elsewhere; they have publicly chafed under the burden of the short deadlines imposed by the understandably nervous editors of law reviews extending offers. ${ }^{149}$

An increasing number of professors have also complained about student editing of articles after selection. ${ }^{150}$ They have expressed concern that their manuscripts are not just reviewed for oversights but are substantively rewritten, often by rule-obsessed editors having a lessthan-perfect sense of either literary style or the legal subject at hand. ${ }^{151}$ They have voiced their frustration with having to watch out for and correct the factual, grammatical, and sometimes even typographical errors that are frequently (if innocently) imported into their texts in this process. ${ }^{152}$ They have taken offense at how some law review editors have treated them: they have variously called the attitudes and practices of student editors "infuriating,"153 "officious,"154 and "arrogan[t],"155 and some have called for the creation of formal

148 See Catherine G. Cahan, Living with the Pressure to Publish or Perish, Student Law., Sept. 1985, at 5 (describing pressure on student editors to publish articles of faculty at their own schools); Jordan H. Leibman \& James P. White, How the Student-Edited Law Journals Make Their Publication Decisions, 39 J. Legal Educ. 387, 405 (1990) (same).

149 A number of law reviews have recently moved to prevent or at least extremely limit law review "shopping" by imposing very short deadlines on would-be authors (which is certain to induce even more dissatisfaction). Lisa Anderson, Law Journals Attack 'Shopping' of Manuscripts, N.Y. Times, July 12, 1995, at B6.

150 See, e.g., Gregory E. Maggs, Just Say No?, 70 Chi.-Kent L. Rev. 101, 103 (1994); Carol Sanger, Editing, 82 Geo. L.J. 513, 517 (1993) (explaining that during editorial pro. cess, articles are transformed "from something written by an author with a distinct voice ... to a composition by student committee").

151 See, e.g., Lindgren, Manifesto, supra note 118, at 531; Rothstein \& Rothstein, supra note 145 , at 10 ; Sanger, supra note 150 , at 517.

152 See, e.g., Lindgren, Manifesto, supra note 118, at 529 (citing case of one scholar who found more than 200 style errors introduced into original manuscript after student edit). Lindgren himself has concluded that "[l]aw-review editors are the most aggressive and ignorant editors you will ever encounter." Shea, supra note 121, at A33 (quoting Lindgren, Manifesto, supra note 118, at 527). In 1995, a problematic edit by the student editors of the Fordham International Law Journal actually led to a lawsuit (ironically brought by a student whose Note had allegedly been mangled). The suit was dismissed on summary judgment, not because there were no serious errors in the Note, but rather because the plaintiff could show no good cause of action in federal law. Choe v. Fordham Univ. Sch. of Law, 920 F. Supp. 44, 49 (S.D.N.Y. 1995).

153 Mark Thompson, The Law Review Meets the Marketplace, Student Law., Dec. 1984, at $14,19$.

154 Ronald D. Rotunda, Law Reviews: The Extreme Centrist Position, 62 Ind. L.J. 1, 10 (1986).

155 Sanger, supra note 150 , at 517. 
codes of ethics to govern editor-author relationships no longer defined by student deference and respect. ${ }^{156}$

Some legal scholars have even lamented how long it takes for a law review article to be first accepted and then published.157 This lamentation is not as insignificant as it might seem; in a highly competitive scholarly marketplace-not to mention a rapidly changing legal environment-the academic and professional worth of an article may be radically diminished if for one reason or another it comes out "late,"158 and especially if it comes out after a similar article in a competing journal. One prominent cause of delays (and other problems) ${ }^{159}$ has ironically been the professorial practice of making simultaneous submissions to multiple law reviews-a strategy originally adopted to ensure rapid article placement. Nowadays, a simultaneous mailing to twenty or more journals is common; ${ }^{160}$ if the initial response is not what the author had hoped, another twenty copies may be sent out, and so on.

The results of such a strategy for individual reviews-especially reviews at the elite schools-have been catastrophic. ${ }^{161}$ In 1983, for instance, it was calculated that the top law reviews received over 200 , and sometimes over 300 , unsolicited manuscripts each per year. ${ }^{162}$ In 1995 , it was estimated that the "elite journals" were swamped by as many as 1200 annual submissions. ${ }^{163}$ In this situation law professors have had to endure longer and longer waits before receiving word on the fate of their submissions. In some instances, and especially at some times of year (generally late fall or winter), law professors wait only to be told that a law review has "filled up," which either forces the professor to go to another review or (what is worse) forces the article to be temporarily withdrawn from a generally saturated mar-

156 See, e.g., Michael L. Closen, A Proposed Code of Professional Responsibility for Law Reviews, 63 Notre Dame L. Rev. 55, 57 (1989).

157 See, e.g., David M. Richardson, Improving the Law Review Model: A Case in Point. 44 J. Legal Educ. 6, 7 (1994).

158 See Lasson, supra note 133, at 933 ("Most often the lag is so long between the first dull gleam in an author's eye and the finished product that whatever might be timely and relevant is largely lost on whatever few readers may be out there. The stuff is simply stale.").

159 See infra notes $172-73$ and accompanying text.

160 Pursuing a rather selective (and perhaps optimistic) placement strategy, I initially submitted the print version of this Article to "only" 14 journals.

161 See generally Erik M. Jensen, The Law Review Manuscript Glut: The Need for Guidelines, 39 J. Legal Educ. 383, 383 (1989) (arguing that law review selection process "has broken down in many cases").

162 Josh E. Fidler, Law-Review Operations and Management, 33 J. Legal Educ. 48, 60 (1983).

163 Tobias, supra note 146 , at 531. Another estimate suggests more than 1500 . See Shea, supra note 121 , at $\mathrm{A} 33$. 
ket. Even after an article is selected and edited, publication may be postponed for weeks or even months because there is a problem with a particular law review issue: another legal scholar has been tardy in correcting proofs, student notes and comments are late, or there are problems or delays at the printer. ${ }^{164}$ All of this inevitably adds up to frustration.

Third, the number and intensity of criticisms of law reviews have increased due to changing patterns of student-faculty interaction in contemporary American law schools. Even in those instances where students had taken over formal control of faculty-run publications, they had continued to seek advice from faculty on editorial and policy matters. ${ }^{165}$ The tradition of student-faculty consultation had resulted in what one writer (perhaps somewhat ambitiously and nostalgically) has called "peer-review . . . of a sort," a practice which encouraged most (albeit certainly not all) law professors to preserve their faith in the law review as a scholarly institution.166 By the early 1980s, however, this practice had largely ceased.167 The last phase of studentfaculty disengagement had begun in the later 1960s, when student editors-directly or indirectly influenced by the rebellious atmosphere on many campuses-became notably reluctant to defer or even consult their former faculty mentors. ${ }^{168}$ Those students still seeking editorial guidance from their professors in the 1970s and early 1980s found that in the increasingly charged academic atmosphere of the time, the latter no longer agreed on the nature or qualities of good scholarship. ${ }^{169}$ Under increasing pressure to write, many professors moreover lacked the time or the inclination to read others' submissions or to give quality advice. ${ }^{170}$ In this context, the editorial process was left "in the hands of young people with little experience in evalu-

164 Cf. Rotunda, supra note 154, at 9 (conceding existence of drawbacks to student-run publications). In 1983, the average law review published two months behind schedule. Fidler, supra note 162 , at 51 . Anecdotal evidence would suggest that by 1995 , that lag had become at least a month or two longer.

165 See, e.g., John G. Kester, Faculty Participation in the Student-Edited Law Revicw, 36 J. Legal Educ. 14, 14 (1986) ("[W]e editors who guarded the lofty independence of even the most-independent-of-all Harvard Law Review in the pre-Jacobin era of a generation ago kept a careful eye cocked on the Harvard faculty. Our professors, in turn, generously supplied counsel that we were clever enough to recognize (if not always admit) we needed.").

166 Id. at 16.

167 Cramton, supra note 60, at 6; see also Dekanal, supra note 6, at 234 (expressing regret at declining faculty participation).

168 See Patricia Bellew Gray, Harvard Faculty Hit for Plan to Start New Law Journal, Chi. Daily L. Bull., May 28, 1986, at 2.

169 Kester, supra note 165 , at $15-16$.

170 Chris Goodrich, Professor, Edit Thyself, Cal. Law., July 1986, at 48, 52. 
ating legal skills, few standards by which to do so, natural naiveté, and scant regard for the institutional future."171

In the process of asserting their own independence from faculty supervision, the student editors of contemporary law reviews have become more assertive in their general dealings with faculty authors. For instance, they have increasingly refused to provide rejected law review authors with substantive written or even oral reasons for their rejection. There is little documentary evidence as to when editors began to abandon the practice of providing reasons, but anecdotes suggest that by the late 1970s it had died out at all but a few institutions, accelerated perhaps by the aforementioned professorial strategy of multiple submissions. Students were too pressed and too stressed to provide reasons or feedback. This deprived faculty of potentially useful input ${ }^{172}$ and unfortunately helped to create an atmosphere in which it was easy to impute improper selection motives to student editors who no longer made even a pretense of offering evidence to the contrary. Growing student assertiveness has also been manifested in the recent turn towards substantial editorial rewriting of submissions. Before the 1970s, significant student rewrites at all but the most elite law reviews were rarely contemplated, let alone attempted. As one veteran of legal scholarship put it, "student editors tended to exercise substantial restraint in the editing process. Errors in grammar and usage were corrected, and suggestions for deletions, additions and reorganization made. ... [As a result] most faculty members actually could recognize their own work when it appeared in print ...."173

The plethora of manuscripts, the amount of work consequently demanded of today's student editors, and the virtually complete independence of those editors from law faculty have together given rise to a fourth cause of contemporary law review criticism: doubts about the traditionally assumed pedagogical value of law review service. Predictably, many of these doubts have been articulated by law professors with other axes to grind. In 1986, for instance, Roger Cramton contended that shepherding manuscripts through a group-decision process and running writing competitions for new staffers "have few educational benefits for anyone and do not contribute in any way to publication of student notes or editing of lead articles."174 Doubts

171 Kester, supra note 165 , at 16.

172 See generally Leibman \& White, supra note 148 , at 423 (asserting that "the failure to provide feedback is the most serious weakness of the law review model").

173 Dekanal, supra note 6, at 236.

174 Cramton, supra note 60 , at 9 (noting large portions of editorial staff efforts devoted to selecting new members); see also Lasson, supra note 133, at 932 (arguing that exclusive nature of law reviews calls scope of their educational value into question). 
about the educational benefits of law review have, however, also been raised by law students themselves. In 1988, a recently graduated Notes Editor of the Georgetown Law Journal concluded that "the law review's academic and creative value is overstated. Many students leave law review with little more to show for their two-year membership than bluebook proficiency."175 In 1990, a disaffected Senior Articles Editor from the Georgetown Journal of Legal Ethics bemoaned a more general and even more pedagogically awkward problem: "I've barely opened my casebooks because the journal takes so much time; I've skipped classes because the journal takes so much time." 176 Law review was actually interfering with this editor's legal education.

A fifth reason why criticisms of law reviews have multiplied dramatically of late relates to law's recent interdisciplinary turn ${ }^{177}$ - the scholarly shift towards studies of law and economics, feminist jurisprudence, law and society, critical race theory, postmodern legal studies, etc. The causes of this turn are still being debated. Changing political and ideological circumstances-e.g., the civil rights movement and the women's movement-have certainly played a role, as has the recent intellectual vigor of such specific disciplines as economics, philosophy, and history, not to mention the general restlessness experienced by many members of law school faculties after a period of dominant doctrinalism. To some extent, the interdisciplinary turn has also been the product of population shifts in the legal academy-in particular, the influx of a high number of former liberal arts students who since the early 1970s have gone into the relatively open field of law and law teaching instead of pursuing more economically risky Ph.D.'s and then assuming professorships in arts and humanities departments. ${ }^{178}$ Whatever its origins, the interdisciplinary turn in legal studies has prompted professorial objections to the judgments of law review editors who, for all their raw interest, have little or no graduate training in other disciplines. Richard Posner, for instance, has recently observed that "[f]ew student editors, certainly not enough to go around, are competent to evaluate nondoctrinal scholarship." 179 Indirectly, the

175 E. Joshua Rosenkranz, Law Review's Empire, 39 Hastings L.J. 859, 860 (1988); sce also id. at $899,899-911$ (positing that "[1]aw review does not make you any smarter-the experience is illusory").

176 Rosemary Harold, Dilemmas: Law Review Isn't What You Think It Will Be. But is Membership Really Worth It?, Student Law., Jan. 1991, at 7.

177 See generally Richard A. Posner, The Decline of Law as an Autonomous Discipline, 1962-1987, 100 Harv. L. Rev. 761 (1987).

178 See Robert Weisberg, Some Ways to Think About Law Reviews, 47 Stan. L. Rev. 1147,1154 (1995) (discussing impact of changing demographics on legal education in America).

179 Posner, supra note 117 , at $1133-34$. 
interdisciplinary turn has stimulated criticism of the status quo by sensitizing legal academics to the scholarly practices of other fields, where student control of academic publishing is unknown and, indeed, ridiculed. It is no accident that James Lindgren, whose interests run from law and sociology to legal history, has lately written that "in other parts of the academy, legal journals are considered a joke. Scholars elsewhere frequently can't believe that, for almost all our major academic journals, we let students without advanced degrees select manuscripts."180

Sixth, law reviews have come in for more criticism as more law review writers have ceased writing about professional, doctrinal, and local issues. In part, this development is a result of the just-discussed interdisciplinary turn. It is also, however, a product of the recent falloff in the number of practitioners and judges-as opposed to law professors-writing for (or allowed to publish in) law reviews, ${ }^{181}$ and of the understandable ambitions of a variety of "lesser" law schools to raise their institutional and scholarly sights above the horizon of their own states and regions. In these circumstances, law reviews have been accused of having become increasingly irrelevant for the practicing bar and the judiciary, two of their traditional constituencies. ${ }^{182}$ Several prominent members of the American bench have openly expressed their frustration with this situation. In a recent article in the Michigan Law Review, Judge Harry Edwards of the U.S. Court of Appeals for the D.C. Circuit volunteered his opinion that "[o]ur law reviews are now full of mediocre interdisciplinary articles."183 Judge Laurence Silberman of the D.C. Circuit has even slammed the law reviews from the bench, accusing them of being "dominated by

180 Lindgren, Manifesto, supra note 118, at 535.

181 In 1960, for instance, judges and practitioners published almost as many articles in law reviews as did professors. Judith S. Kaye, One Judge's View of Academic Law Review Writing, 39 J. Legal Educ. 313, 320 n.33 (1989) (citing Michael Saks's January 1989 presentation of research for law joumal study to symposium on legal scholarship). By 1985, however, articles by professors outnumbered those by judges and practitioners by more than three to one. Id.

182 See Cramton, supra note 60, at 10 (noting that law review articles are remote from practitioners' problems); Max Stier et al., Law Review Usage and Suggestions for Improvement: A Survey of Attorneys, Professors, and Judges, 44 Stan. L. Rev. 1467, 1498 (1992) (reporting results of survey indicating that judges and attorneys found contemporary law review articles too theoretical); Law Reviews: A Waste of Time and Money?, Am. Law., Apr. 1994, at 50 (quoting on-line expressions of dissatisfaction with lav reviews from members of legal profession).

183 Harry T. Edwards, The Growing Disjunction Between Legal Education and the Legal Profession, 91 Mich. L. Rev. 34, 36 (1992). 


\section{[the] rather exotic offerings of increasingly out-of-touch faculty members."184}

Seventh, criticisms of law reviews have multiplied because in the last fifteen years, law professors have tended to produce articles that are on average longer and more heavily annotated than those written, say, forty years ago. 185 In part, this lengthening and substantiating process has been prompted by the desire of assistant and associate law professors to demonstrate their scholarly capabilities to increasingly demanding tenure and promotion committees, ${ }^{186}$ not to mention increasingly selective law review boards. ${ }^{187}$ In part, the process has also been driven by law professors' needs to differentiate their individual submissions from those of an increasingly large number of scholarly competitors; ${ }^{188}$ it has only been encouraged by professors' recognition that interdisciplinary articles submitted to law student editors (not to mention other law professors) often require more extended explanation and documentation than they would require if submitted to informed academics in the arts, humanities, and social sciences. ${ }^{189}$ It has additionally been suggested that student editors have actively contributed to the problems of length and extended footnoting through an overenthusiastic adherence to Bluebook form and a concomitant desire to impress their editorial board colleagues by displays of footnote

184 United States v. $\$ 639,558$ in United States Currency, 955 F.2d 712, 722 (D.C. Cir. 1992) (Silberman, J., concurring).

185 On the increasing length of contemporary law review articles, see $W$. Lawrence Church, A Plea for Readable Law Review Articles, 1989 Wis. L. Rev. 739, 740 (reporting that in 1936-1937, length of average leading article in Wisconsin Law Review was 13 pages; in 1962, 36 pages; and in 1988, over 44 pages); Elyce $H$. Zenoff, I Have Seen the Enemy and They Are Us, 36 J. Legal Educ. 21, 21 n.1 (1986) (noting that for 17 of 20 law reviews surveyed, length of articles in first issue of current volume was longer on average in 19841985 than in 1954-1955). On the history, function, and problems associated with footnotes, see generally Austin, supra note 135 (discussing authors' uses of footnotes to differentiate their articles and to give impression of scholarly depth); Lasson, supra note 133, at 937.41 (arguing that negative effects of footnote proliferation outweigh positive effects); William R. Slomanson, Footnote Logic in Law Review Writing: Previously Unaddressed in the Criminal Justice System, 9 Crim. Just. J. 65 (1986).

186 This is consistent with the results of a 1983 study which indicated that as legal academics rose through the tenure track (from Acting Professor to Assistant Professor, Asso. ciate Professor, Professor, and Dean) and consequently had fewer promotional concerns, they produced articles with fewer pages, fewer footnotes, and fewer footnotes per page. See Ellman, supra note 147, at 683 (analyzing study's statistics broken down by rank and occupation of author).

187 Lindgren, Manifesto, supra note 118 , at 531.

188 See Austin, supra note 135 , at $1141-43$ (describing "numbers game" played by "[n]eophyte writers [who] have a tendency to go for quantity").

189 The footnote "problem" in particular has also been exacerbated by the traditional absence of bibliographies in law review articles. If bibliographies were common, law professors might feel less compelled to annotate in order to show they had read or consulted a particular work, or to point readers to that work. 
finesse. Unfortunately, the presence of longer and more heavily documented articles in law reviews has attracted the ire of many impatient and/or aesthetically displeased readers from both inside and outside the professoriate. ${ }^{190}$ In 1983, the desire for more concise, more visually attractive, and more lively articles was a major factor prompting Professor Richard Stewart of the Harvard law faculty to author an internal memorandum recommending the creation of a faculty-edited law journal. ${ }^{191}$

Finally, law reviews have become more controversial as law students' social attitudes and writing abilities have changed. Egalitarianism has continued to work its magic on law review boards, an increasing number of whose members have lost faith in both "grading on" and "writing on" as impartial arbiters of merit.192 By the late 1970s, the Stanford Law Review and Yale Law Journal had opened themselves up to student volunteers. ${ }^{193}$ In the. 1980 s, many studentedited legal journals formally or informally embraced affirmative action as a way of extending the benefit of law review participation to more women, minorities, and other persons from disadvantaged backgrounds (including the poor, the disabled, and gays and lesbians). The Harvard Law Review set off a storm of controversy when it inaugurated an affirmative action policy in $1981 ; 194$ by 1983 , however, eight law reviews had nonetheless followed suit. ${ }^{195}$ Also since the early

190 See, e.g., Austin, supra note 135, at 1133-35 ("A chorus of crities argue that footnotes have become a serious embarrassment to legal scholarship . ..."); Alfred F. Conard, A Lovable Law Review, 44 J. Legal Educ. 1, 1 (1994) (claiming to "love brevity"); Ronald B. Lansing, The Creative Bridge Between Authors and Editors, 45 Md. L. Rev. 241, 248-50 (1986) (complaining about number of footnotes per article); Stier et al., supra note 182, at 1499 (reporting results of survey in which most professors, judges, and attorneys agreed that articles should be shorter and less heavily footnoted). For a discussion of footnoting problems, see generally Church, supra note 185.

191 Thompson, supra note 153, at 17.

192 On the limited value of the "writing competition," see Rosenkranz, supra note 175 , at 894-97 (arguing that writing competitions cannot measure research skills and do not measure analytic skills).

193 Joel Seligman, The High Citadel 182 (1978).

194 See Drawing Distinctions at Harvard Law, N.Y. Times, Mar. 3, 1981, at A18 (claiming that "a fixed standard of merit is being abandoned for only the vaguest reasons of social good"); Harvard Law Review's Ethnic Screening Criticized, N.Y. Times, Feb. 24, 1981, at A12 (discussing objections to Harvard's policy). After female editors voted against its application to themselves, the Review's affirmative action policy ultimately did not extend to women. Perhaps consequently, women made up a mere 11 of the 44 new members on the most recent (1995-1996) Harvard Law Review board. Tara Dawood, Law Review to Study Gender Disparity, Harv. L. Rec., Oct. 20, 1995, at 1.

195 Fidler, supra note 162, at 53 (reporting results from New York University Law Review Alumni Association survey). Controversy over law review affirmative action policies nonetheless continued beyond this initial period of implementation. See, e.g., Scholarly Schism, 75 A.B.A. J. 50 (1989) (discussing affirmative action on George Washington Law Review). 
1980s, more and more students have become involved in the law review editing process via the multiplication of specialty journals. At least some academic commentators have alleged that these developments have significantly "watered down" the already dubious editorial quality of the law reviews. ${ }^{196}$ This accusation has become even more serious in light of what most law professors regard as a general decline in the writing abilities of today's law students. This decline has allegedly been reflected in both the poor quality of many editorial rewrites and editors' increasingly slavish devotion (presumably born of uncertainty and inexperience) to the technical standards of the Bluebook or some other obtuse style manual. ${ }^{197}$

Even in the face of all these developments and the (sometimes severe) criticisms they have encouraged, certain law professors, legal practitioners, and an increasing number of law students have insisted on coming to the law review's defense one more time. ${ }^{198}$ Their counterarguments have not, however, precluded significant attempts to further reform the law review system. ${ }^{199}$ One reform has entailed the formal or informal adoption of editorial policies more explicitly deferential to faculty authors. In 1994, for instance, the articles editors of the University of Chicago Law Review publicly promised to show "substantial deference," by which they meant that they would respect the author's "voice" and would give the author final say on whether suggested changes would be made. ${ }^{200}$ A second reform, recently inaugurated in the offices of the Yale Law Journal, has substi-

196 Cramton, supra note 60, at 8-9; Lasson, supra note 133.

197 See generally Lindgren, Fear of Writing, supra note 118, at 1678 (claiming Texas Law Review Manual on Style represents "one of the most pernicious collections of superstitions that has ever been taken seriously by educated people"); Richard A. Posner, Goodbye to the Bluebook, 53 U. Chi. L. Rev. 1343, 1349-51 (1986) (claiming that "[t]he Bluebook creates an atmosphere of formality and redundancy" and providing examples "of the antilessons that our heavily student-influenced legal culture enforces").

198 See, e.g., Wendy J. Gordon, Counter-Manifesto: Student-Edited Law Reviews and the Intellectual Properties of Scholarship, 61 U. Chi. L. Rev. 541 (1994); John Paul Jones, In Praise of Student-Edited Law Reviews: A Reply to Professor Dekanal, 57 UMKC L. Rev. 241 (1989); Joseph R. Julin, Faculty-Edited Law Review: No - A Statement by Joseph R. Julin, 16/3 Syllabus 1 (1985); Scott M. Martin, The Law Review Citadel: Rodell Revisited, 71 Iowa L. Rev. 1093 (1986); Rotunda, supra note 154, at 9 (noting virtues of present law review system); Michael Vitiello, In Defense of Student-Run Law Reviews, 17 Cumb. L. Rev. 859 (1987) [hereinafter Vitiello, In Defense]; Vitiello, supra note 140; The Articles Editors, A Response, 61 U. Chi. L. Rev. 553 (1994); Phil Nichols, Note, A Student Defense of Student Edited Journals: In Response to Professor Roger Cramton, 1987 Duke L.J. 1122.

199 See, e.g., Lindgren, Reforming, supra note 118, at 1123 ("The law review reform movement is coming of age. As this symposium attests, at least the targets of our criticism are beginning to listen."); Vitiello, supra note 140, at 930 ("[T]here has been positive change in format and content of what many law reviews are publishing.").

200 The Articles Editors, supra note 198, at 558. 
tuted "blind" article selection for the traditional "full disclosure" variety in an effort to avoid the appearance of bias. ${ }^{201} \mathrm{~A}$ third reform has involved a greater tolerance of (and in some instances, even a formal encouragement of) nontraditional styles of scholarship and academic writing, especially those favoring brevity. In 1985, for instance, the Michigan Law Review inaugurated a "Correspondence" section allowing its readers an opportunity to formally react to articles appearing in its pages. ${ }^{202}$ Later the same year, the Harvard Law Review started a "Commentary" section featuring brief comments by legal scholars on topical issues, ${ }^{203}$ while Yale launched "Essay" and "Dialogue" sections that offered legal scholars new ways to present and respond to ideas. More recently, a number of journals have published fictionalized or actual dialogues, ${ }^{204}$ playscripts, ${ }^{205}$ and even poetry ${ }^{206}$ in an effort to expand their stylistic range. A fourth, somewhat more traditional reform has resulted in an increasing number of studentedited law reviews adopting a symposium format in the hopes of making their contents more appealing (and more noticeable) to welldefined academic and professional constituencies.207 A fifth reform has been entrepreneurial in orientation: recognizing their precarious position in both a saturated academic community and an austerityridden institutional environment, "spin off" law reviews such as the Yale Journal on Regulation have consciously undertaken to market

201 Lindgren, Reforming, supra note 118, at 1129. In "blind" article selection, students considering articles are not privy to the identities, institutional affiliations, or curriculum vitaes of faculty authors.

202 John C. Metaxas, Two New Faculty-Edited Joumals Enter the Legal Scholarship Arena, Nat'l L.J., Jan. 27, 1986, at 4. On the general proliferation of "Correspondence" sections, see Erik M. Jensen, Law Review Correspondence: Better Read than Dead?, 24 Conn. L. Rev. 159 (1991).

203 John C. Metaxas, Harvard Law Review Inaugurates an Informal 'Commentary' Section, Nat'l L.J., Dec. 16, 1985, at 4.

204 E.g., Richard Delgado \& Helen Leskovac, The Politics of Workplace Reforms: Recent Works on Parental Leave and a Father-Daughter Dialogue, 40 Rutgers L. Rev. 1031, 1039-58 (1988) (presenting fictional dialogue on "parental leave's ability to benefit or harm women").

205 E.g., Victor Bolden, Judge Not, That Ye Be Not Judged: A Dramatic Call for a More Enlightened Approach to Judicial Decision-Making in Race Discrimination Cases, 7 Harv. BlackLetter J. 33 (1990) (presenting play "on how judges ought to look at themselves and how they consider deciding cases").

206 See, e.g., A. Sirico, Supreme Court Haiku, 61 N.Y.U. L. Rev. 1224 (1986) (reducing notorious cases to six poetic moments).

207 See generally Executive Board, The Symposium Format as a Solution to Problems Inherent in Student-Edited Law Journals: A View from the Inside, 70 Chi.-Kent Lo Rev. 141, 141 (1994) (discussing "degree to which the Chicago-Kent Law Reviev's symposium format works to solve [various] problems"); Jean Stefancic, The Law Review Symposium Issue: Community of Meaning or Re-inscription of Hierarchy?, 63 U. Colo. L. Rev. 651 (1992) (examining proliferation of symposium issues). 
themselves to a broader buying and subscribing public. ${ }^{208}$ This initiative has inevitably made their substance and style more colloquial.209 A sixth reform has been even more radical: the inauguration of an increasing number of faculty-edited law journals (mostly specialized or symposium-based) pointedly providing peer review, feedback, the guidance of experienced editors, stylistic flexibility, timely publication, and/or other advantages not generally offered by student-edited law reviews. ${ }^{210}$ Some of these publications-such as the University of Minnesota's Constitutional Commentary (1984) and the University of Florida's Florida Tax Review (1992) - are brand new. Others-such as the University of San Diego's Journal of Contemporary Legal Issues and the Chicago-Kent Law Review ${ }^{211}$-have come into being after complete or partial faculty "takeovers" of student-edited publications. ${ }^{212}$

The latest reforms of the law review system may be improvements, but for all the hope and hype attending them it is unlikely that they will prove all that effective in the long run. "Editorial deference" is a notoriously vague concept that (judging by anecdotal evidence) is more often the exception than the norm. Notwithstanding its apparent success at Yale, 213 the "blind read" selection strategy is time consuming and hardly foolproof insofar as authors can reveal themselves and their schools in multiple ways; 214 besides, although blind reading removes a temptation, it does nothing to positively raise the standards of the student-run selection process. Dialogues, poems, essays, and

208 See generally Thompson, supra note 153 .

209 "We aimed for something more in-depth than Harper's or Atlantic but not as dry or as boring as a standard law review." Thompson, supra note 153, at 16 (quoting a former editor of the Yale Journal of Law and Politics).

210 See generally Richard A. Epstein, Faculty-Edited Law Journals, 70 Chi.-Kent L. Rev. 87 (1994).

211 On the new regime at the Chicago-Kent Law Review, see Randy E. Barnett, Beyond the Moot Law Review: A Short Story with a Happy Ending, 70 Chi.-Kent L. Rev, 123 (1994).

212 Not all attempts at faculty takeover have been completely successful. Al George Mason University, for instance, the faculty's declared intention to assume control of the fiagship student-run law review generated such controversy that the students began an "independent" law review (appropriately named the George Mason Independent Law Review). The faculty ultimately agreed to a compromise which allowed students to maintain control over article selection and editing in the main journal, although at the same time the faculty insisted that it include only student-written articles. For discussions of the attempted faculty "coup," see Stier et al., supra note 182, at 1504 n.112; Lisa Schkolnick, Review Revamp Raises Ire at George Mason, Student Law., Jan. 1992, at 47.

213 See generally Lindgren, Reforming, supra note 118, at 1129.

214 The Articles Editors, supra note 198, at 554-55 (stating that writing style, among other things, may give authors' identities away); see also Rebecca M. Blank, The Effects of Double-Blind versus Single-Blind Reviewing: Experimental Evidence from the American Economic Review, 81 Am. Econ. Rev. 1041, 1045 (1991). 
letters are marginal formats which to date have instilled little enthusiasm in tenure and promotion committees. The symposium format, while a standard "fix" for certain law review problems, also has equally standard problems. ${ }^{215}$ Making law reviews into profit-seeking institutions runs the risk, over time, of undermining their primarily academic mission. However attractive faculty-edited journals might be in the abstract, few law professors have the time or the inclination (without substantial economic or professional reward) to do quality editing or prompt refereeing when they might be writing articles or books themselves. ${ }^{216}$ It is not irrelevant in this connection that despite the proliferation of faculty-edited reviews in the last decade, two very high-profile experiments in faculty editing announced in the mid1980s (one at Harvard and the other under the auspices of the AALS) ${ }^{217}$ failed ignominiously before they even began.218 Judging from experiences outside legal academia, and even from reported experiences inside it, it must also be admitted that faculty journals have editorial weaknesses of their own: they can easily become hidebound, their boards can be "captured" by particular viewpoints or schools of thought, and their editors can select articles on scholastically illegitimate or arbitrary grounds. ${ }^{219}$ The putative ascendancy of facultyedited journals might even compromise law professors' abilities to get their work placed: in all likelihood, a faculty-dominated law review

215 See supra text accompanying note 88; see also Executive Board, supra note 207, at 143-46 (noting that "[ $t]$ he symposium format gives rise to a number of problems" including publishing delays due to the "slowest article," authors" withdrawals of articles, additional bureaucratic layer in form of faculty symposium editor, and relinquishment of student control over topic and article selection).

216 See Rotunda, supra note 154, at 6.

217 On the controversy surrounding the Harvard initiative, see Gray, supra note 168, at 2. The proposal that the AALS sponsor a journal was originally flosted by its thenPresident, Roger Cramton, in 1985. Cramton, supra note 60, at 9-10. On the two proposals generally, see Metaxas, supra note 202.

218 On the failure of the Harvard journal, see John C. Metaxas, Harvard Faculty Journal Loses Tribe to Bicentennial of the Constitution, Nat'l L.J., July 21, 1986, at 4 (discussing resignation of Laurence Tribe, designated editor of faculty-edited Harvard law journal, so that he could devote his attention to other scholarly endeavors).

219 Horror stories about peer review in the arts and sciences are common. In one particularly provocative experiment on the objectivity of the process, researchers selected a dozen articles written by well-known authors that had recently appeared in respected journals, resubmitting them to the same joumals with the names of the original authors deleted. The journals and their appointed referees (two per article) rejected eight of the twelve resubmitted pieces, citing poor scholarship and poor writing. Douglas P. Peters \& Stephen J. Ceci, Peer-Review Practices of Psychological Joumals, 5 Behavioral \& Brain Sci. 187, 187-90 (1982); see also Mary Biggs, The Impact of Peer Review on Intellectual Freedom, 39 Libr. Trends 145, 157-58 (1990) (discussing Peters \& Ceci study). 
system would mean that fewer outlets would be available for the same amount of scholarly output. 220

More important for present purposes, the efficacy of all these reforms is ultimately limited by most of them having been attempted within the physical and intellectual confines of traditional print technology. Having lost sight of how technology contributed to the creation and development of law reviews in the first place, all but a few would-be reformers have to this point failed to consider how new technologies-in particular, computer-mediated communication technologies - might be deployed to break the impasses of the current law review system.

In fact, of course, computer-mediated communications technologies are already at work in the legal academy. Not only are they subtly changing how law reviews are used, but they are (for the most part) increasing the latter's scholarly and professional value. They are even meeting some of the criticisms lately articulated by the law review's detractors. In the next section of this Article, I explore the development of two manifestations of these computer technologieson-line databases (LEXIS/WESTLAW) and Internet electronic journals-with a view to demonstrating both their impact and their limitations as new forms of scholarly communication in law.

\section{III}

\section{LAW REVIEWS ON-LiNe}

Today's on-line legal databases originated as a technological response to mid-twentieth-century complaints about the unregulated proliferation of legal literature. Such complaints already had a long history in the American legal community, 221 but from the 1940s through the early 1960s their intensity increased dramatically 222 as American lawyers found themselves confronting a collection of postwar statutes, precedents, and professional periodicals (including, of course, law reviews) that was growing at an unprecedentedly rapid

220 Vitiello, In Defense, supra note 198, at 872-73.

221 In addition to the sources cited supra note 27, see Roscoe Pound et al., Report of the Special Committee to Consider and Report as to the Duplication of Law Books and Publications, 61 A.B.A. Rep. 848 (1936); Samuel H. Sibley, The Multitude of Published Opinions, $25 \mathrm{~J}$. Am. Judicature Soc. 166, 166 (1942) (arguing that "courts of last resort ... or the legislatures, ought to restrain the publication of those [opinions] not of general importance").

222 See, for instance, Eugene M. Prince, Law Books, Unlimited, 48 A.B.A. J. 134, 134 (1962) ("Lawyers know that there are too many law books, but not every lawyer realizes how many, or how critical a problem these books present."). 
pace.223 The legal literature was multiplying so fast that it threatened not only to bankrupt many attorneys 224 but also to overwhelm the indexing systems that had traditionally corralled and categorized it. Even presuming that the standard legal indexes could conceptually and physically keep up with the rush of new material (a problematic presumption at best), ${ }^{225}$ they were themselves becoming so large and awkward that they almost defeated their own purposes. ${ }^{226}$

In these circumstances, an eclectic variety of lawyers, legal academics, and law librarians looked to emerging computer technology to facilitate the storage, accessing, and distribution of legal information. 227 Computers had been developed for military purposes during World War II; in the mid-1950s they had entered the commercial market. Here, then, was a likely tool for the times: one which could eventually make the mountains of paper law physically manageable again,

223 For extensive documentation (complete with graphs), see Layman E. Allen et al., Automatic Retrieval of Legal Literature: Why and How 1-22 (1962); see also Robert A. Wilson, Computer Retrieval of Case Law, 16 Sw. L.J. 409, 409 (1962) ("Each year about 25,000 new opinions are published (nearly 700 cases per day) along with over 29,000 new statutes.").

224 Prince, supra note 222, at 135 (estimating that in 1961, establishing a minimum "adequate working library" for extensive state, federal, and administrative practice vould cost $\$ 100,000$, and $\$ 30,000$ per year thereafter to maintain it).

225 See, e.g., Irving Kayton, Retrieving Case Law by Computer: Fact, Fiction, and Future, 35 Geo. Wash. L. Rev. 1, 1-6 (1966) ("The inherent problems of legal indices and digests are compounded by the extraordinarily large amounts of case law and other legal materials printed and disgorged daily."); Wilson, supra note 223, at 410 (discussing problems with breadth and identity of traditional indexing categories).

226 See Jessica S. Melton \& Robert C. Bensing, Searching Legal Literature Electronically: Results of a Test Program, 45 Minn. L. Rev. 229, 230 (1960) ("With each passing year, we pile up decision on statute on rule on regulation and then construct large and cumbersome digests, compendiums, indexes and other archeological devices which we hope will help us find what we want in the evergrowing mound." (quoting Counsel to the Governor of New Jersey, Vincent P. Biunno, Progress and New Developments in Electronic Research for the Lawyer, Address at the Meeting of the American Bar Association in Miami, Fla. (Aug., 1959))); Wilson, supra note 223, at 409 (discussing "the overtaxing of the traditional indexing systems, and the increasing inability of these systems to meet the research needs of the lawyer whose clients are more and more demanding faster answers to their growing legal problems").

227 See, e.g., Roy N. Freed, Prepare Now for Machine-Assisted Legal Research, 47 A.B.A. J. 764, 764-67 (1961) ("Substantial advantages are in store for lawyers from the use of machines and appropriate indexing techniques to aid in legal research."); Lavrence A. Harper, Legal Research, Technology and the Future, 24 State B. Cal. J. 104, 111 (1949) ("If in ' 49 the State Bar starts a serious investigation of the possibilities of mechanical aids to legal research ... it should help to hasten the day when the attorney is emancipated from the slavery of routine research and freed to practice law."); Louis O. Kelso, Does the Law Need a Technological Revolution?, 18 Rocky Mtn. L. Rev. 378, 385-92 (1946) ("The American bar will do well to think seriously of mechanizing the drudgery of the practice of law, in order that the really irreplaceable human contributions may be liberated for the benefit of mankind."); J.M. Jacobstein, Note, Scientific Aids for Research, 31 Chi.-Kent L. Rev. $236,243-45$ (1952) (discussing necessity of electronic searching machine for legal research). 
which could make retrieval of legal information faster, cheaper, and more accurate than ever before, ${ }^{228}$ and which into the bargain could create entirely new legal communication and research strategies.

The first successful experiments in what we now call "computerassisted legal research" (CALR) were performed in the late 1950s and early 1960s by John Horty, Director of the University of Pittsburgh Health Law Center and, from 1960, an adjunct professor at the University of Pittsburgh School of Law. In an effort to facilitate research into the public health laws of Pennsylvania, Horty had the texts of all the relevant statutes coded onto punch-cards and then put on computer tapes where they could be rapidly searched and retrieved by keyword (technically "Key Words in Combination" (KWIC)). ${ }^{229}$ In 1960, Horty demonstrated his search and retrieval system at the Annual Meeting of the American Bar Association. 230 In later years, he extended his root database to include the texts of all Pennsylvania statutes, the opinions of the Pennsylvania Attorney General on education, the complete statutes of New York, the health law statutes from eleven other states, and even the decisions of the United States Supreme Court and the Pennsylvania Court of Common Pleas. ${ }^{231}$

Horty's system was ingenious and remarkable in many ways, but it had significant limitations.232 In 1967, these limitations prompted the Ohio State Bar Association to create a not-for-profit corporation called Ohio Bar Automated Research (OBAR) which in turn contracted with an Ohio company called Data Corporation for the development of an improved variety of legal research software. ${ }^{233}$ In 1969,

228 Freed, supra note 227, at 766 ("Professionals devote considerable time to poring through indices for citations and to chasing down the books to check on relevance. By finding relevant references faster and by reducing the percentage of irrelevance, machines will contribute real economies....").

229 See John F. Horty, The "Key Words in Combination" Approach, M.U.L.L.: Modern Uses of Logic in Law, Mar. 1962, at 54, 57; see also id. at 62 ("The easy availability of this information means that, for the first time, it will be possible to analyze the contexts in which selected words used in statutes appear."). Apart from Horty's own circumstances, "[s]tatutes were the first area of the law to be adapted to computer research since the precision of their language made a search system based on a full text relatively feasible." Note, Science-Computers-The Use of Data Processing in Legal Research, 65 Mich. L. Rev. 987, 988 (1967).

230 F. Reed Dickerson, The Electronic Searching of Law, 47 A.B.A. J. 902,902 (1961).

231 See Gerald W. Davis, Automatic Data Processing and the Judge Advocate General's Corps, 23 Mil. L. Rev. 117, 129 (1964); David T. Moody, Note, Legal Research: Computer Retrieval of Statutory Law and Decisional Law, 19 Vand. L. Rev. 905, 909 n.9 (1966).

232 In particular, it was "off-line" (i.e., operated by technicians rather than by rescarchers with direct computer access), and it was minimally interactive (meaning that users had limited opportunity to refine searches in progress).

233 William G. Harrington, A Brief History of Computer-Assisted Legal Research, 77 Law Libr. J. 543, 547-48 (1984-1985). 
Data Corporation was acquired by Mead Corporation; a subsidiary of the latter, Mead Data Central, continued the OBAR project and eventually acquired all rights to it from OBAR itself.234 By 1972 , Mead Data Central had produced a second-generation version of the OBAR software which retained many of the best features of the Horty system. ${ }^{235}$ In April 1973, a modified version of this software (together with dedicated hardware) was introduced to the American legal community under the name LEXIS. ${ }^{236}$ LEXIS initially offered its subscribers a database of full-text federal statutes and case law, a federal tax library, and selected state databases (including, of course, Ohio); in 1980, it expanded to give its subscribers access to NEXIS, a huge database of news and business information. ${ }^{237}$

The same year that LEXIS went on-line, the West Publishing Company began work on a CALR system of its own called WESTLAW. ${ }^{238}$ The first WESTLAW system-based on West's famous headnotes-went into operation in April 1975, but it was not until December 1976 that West undertook a full-text service that could effectively compete with LEXIS.239 Software problems complicated the development of WESTLAW to the point where, in 1980, it was thoroughly redesigned. ${ }^{240}$ In the meantime, as well as afterwards, West pursued an aggressive program of database enhancement which allowed its subscribers to access more and more case law, more state databases, and more research options outside of the traditional West system. ${ }^{241}$

Originally, neither LEXIS or WESTLAW carried law review articles, 242 despite the fact that law reviews were contributing to the proliferation of legal literature almost as much as courts and legislatures. The initial disinclination of both services to include law review material can be attributed to several factors. First, the primary commercial targets for both LEXIS and WESTLAW-practicing attorneys-used law reviews far less frequently than they used case law and statutes; it consequently made sense for both systems, as commercial endeavors, to place more emphasis on the development of the

\footnotetext{
234 Id. at 550.

235 Id. at 551.

236 Id. at 552-53.

237 Id. at 552.

238 Id. at 553.

239 Id. at 553-54.

240 Id. at 554.

241 Id.
}

242 Howard A. Hood, Disk and DAT: Recent Developments in Legal Databases and Emerging Information Technologies in the United States, 15 Int'l J. Legal Info. 109, 112 (1987). 
more relevant case- and statute-searching services. Second, law review material was not as massive nor as badly indexed as case and statutory material; it was therefore in less need of a technological fix. Third, law review material was copyrighted, whereas judicial decisions and statutes were not; as a result, legal access to law review material was limited, making it more difficult and potentially more expensive to provide electronically.

In 1982, however, both LEXIS and WESTLAW decided to enter the law review arena. ${ }^{243}$ In all likelihood, they had multiple motivations for their decisions. As an initial matter, they doubtless sought to broaden their scopes as legal information providers. They also had an interest in broadening their clienteles: including law reviews in their databases would make their services more useful and hence more attractive to law professors and law students. Finally, they presumably saw a business opportunity in an area which had become increasingly complex and confused in the wake of the radical expansion of law review literature that had begun in the 1970s and which, in the early 1980 s, showed every sign of continuing.

LEXIS and WESTLAW nonetheless adopted different market strategies in making law review articles available on-line. LEXIS chose the "intensive" route, covering all articles in thirty selected legal journals. ${ }^{244}$ WESTLAW chose to be "extensive," i.e., to include more law reviews but to be selective in choosing which articles in those reviews were actually included. ${ }^{245}$ Both strategies had obvious limitations, but WESTLAW's proved particularly problematic because researchers could not be sure that they were getting all relevant articles in the law reviews WESTLAW carried. ${ }^{246}$ This inevitably created pressure to check manually through the same material, a frustrating situation that LEXIS avoided by definition (although its limitations obviously required manual searching of law reviews not included in its database). WESTLAW subsequently decided to offer full coverage of the top law journals, and since the mid-1980s both LEXIS and WESTLAW have extended their range of law review coverage, with WESTLAW enjoying a considerable edge as of this writing. ${ }^{247}$

Together, LEXIS and WESTLAW have subtly changed the way in which law review material is distributed, accessed, and employed by

243 Id.

244 Id.

245 Id.

246 Id.

247 WESTLAW carries well over 400 law journals and reviews. West Publishing Corp., WESTLAW Database List, Winter/Spring 1996, at 180-207. LEXIS carries barely over 300. LEXIS-NEXIS, Directory of Online Services 111-14 (1996). 
many members of the American legal community.248 Most of these changes have made law reviews more useful. First, LEXIS and WESTLAW allow virtually immediate access to law review articles upon publication. Where once a law professor or practicing lawyer had to wait for the arrival of the printed journal in the mail, or (after arrival) wait his or her turn on the internal routing list, he or she can now read a law review article as soon as it is officially released to the database companies. Second, LEXIS and WESTLAW offer unprecedentedly convenient access to published law review material: articles, notes, and comments can be read from the convenience of a reader's desk at almost any time of the day or night. Third, LEXIS and WESTLAW provide guaranteed access: a law professor or other legal researcher is no longer at the mercy of other readers or borrowers who remove a needed law review volume from its appointed place in the law library. Fourth, LEXIS and WESTLAW allow for specific (keyword) searches of law review materials. Fifth, LEXIS and WESTLAW make it much easier for law professors to bring their ideas to members of the legal profession who otherwise might subscribe to only a handful of printed law reviews. ${ }^{249}$ Finally, using LEXIS and WESTLAW search strategies, legal academics in particular can check how often specific articles have been discussed or cited, giving them (for good or ill) a more accurate sense of trends in legal literature and legal thought. 250

Some of the changes in law review distribution and usage prompted by LEXIS and WESTLAW address some of the complaints that have been made about printed law reviews (an observation which, inter alia, underlines the good business judgment of the database companies in extending their coverage to law reviews in the first place). Most obviously, the electronic databases relieve the physical burden of the current law review system; no longer need law professors drown in a sea of paper every month, or every quarter. At the same time, at least under current WESTLAW and LEXIS licens-

248 See generally M. Ethan Katsh, Law in a Digital World 66-69 (1995) (discussing how "the growth of electronic sources of information changes the nature of information seeking activities because the context of information seeking is different").

249 See Peter W. Martin, How New Information Technologies Will Change the Way Law Professors Do and Distribute Scholarship, 83 Law Libr. J. 633, 635 (1991) (arguing that professors "will soon realize that to reach the widest possible audience of lawyers and judges with an article or its equivalent, the writing itself must be distributed electronically" and that "[p]ublication in WESTLAW and LEXIS, via the law review files, is already a more effective distribution path to members of the legal profession than print alone").

250 Having said all this, however, it must be admitted that in at least one way the electronic database services have made law reviews less useful: given the ease with which case and statute law now can be researched, attorneys and judges have become less inclined to use law reviews as comprehensive guides to legal materials on a particular subject. 
ing arrangements, the databases potentially lower the mounting cost of keeping up with legal scholarship: a law school that subscribes to WESTLAW and/or LEXIS has the option of discontinuing its subscription to the printed version of certain law reviews, or at least cutting back on the number of redundant copies (of high-profile reviews in particular) that it regularly orders.

LEXIS and WESTLAW, however, do nothing to address the more substantive problems plaguing today's law review system. They provide new ways of delivering and accessing legal scholarship, but they leave the institutional structure of the law reviews intact. They do not supplant existing editorial boards, nor do they change the way in which members of those boards select and edit articles. They are dependent on existing publication schedules at individual schools. They are, in other words, conservative information technologies which do not fundamentally challenge or improve the present scheme of scholarly communication.

It may be argued that the inherent conservatism of LEXIS and WESTLAW has indirectly contributed to the development of a new form of computer-mediated legal scholarship: the electronic law journal. Electronic journals (e-journals) in general are creatures of the Internet, a loose system of interconnected worldwide computer networks that can trace its origins to the American military Advanced Research Projects Agency Network (ARPANET) of the late 1960s.251 E-journals were initially conceived (and in more conservative quarters, are still regarded) as electronic editions of print journals or newsletters that would simply duplicate-or, perhaps more accurately, try to duplicate-all or part of their printed content electronically and would then distribute that duplicated content to subscribers having Internet access. ${ }^{252}$ At first instance, this distribution was accomplished through electronic mail (e-mail), then (from 1992) through a more sophisticated Internet retrieval system called "Gopher." Today, more and more print journals (such as Modern Language Notes ${ }^{253}$ and the British Medical Journal ${ }^{254}$ ) are being made available electronically

251 On the history and development of the Internet, see, e.g., Richard W. Wiggins, The Internet for Everyone: A Guide for Users and Providers 5-10 (1995).

252 Bill Gates describes this typical first step:

Whenever a new medium is created, the first content offered is brought over from other media. . . . So far the vast majority of content on-line has been "dumped" from another source. Magazine or newspaper publishers are taking text already created for paper editions and simply shoving it on-line, often minus the pictures, charts, and graphics.

Bill Gates, The Road Ahead 126 (1995).

$253<\mathrm{http}: /$ muse.jhu.edu/journals/mln/index.html $>$.

$254<\mathrm{http}: /$ www.bmj.com/bmj/index.html $>$. 
on the World Wide Web. This revolutionary and rapidly growing25s Internet platform not only has the capacity to understand and carry its predecessors, but can additionally support multimedia (text, images, sound, and video) and "hypertext" (a revolutionary "reading" method which allows Web users to "link" from document to document by following keyword, phrase, or icon connections embedded in particular Web "pages").256 Growing confidence in the electronic medium has meanwhile encouraged the creation and even faster proliferation of a second generation of electronic journals which are solely electronic, having no print equivalents. Many of these, such as Psycoloquy257 and Postmodern Culture, 258 are similarly accessible via the Web and are positioned, at least theoretically, to present information in ways which print technology cannot. Moreover, they have the ability to update their contents not just by producing new material, but by correcting and revising material already placed on-line (something that print-derived e-journals cannot do even in their electronic versions, which by definition have to be print-based).

The first American law review to be distributed electronically in full-text outside of LEXIS and WESTLAW259 was the Federal Communications Law Journal (Indiana University, Bloomington), which in early 1994 began to provide a Web version of its current printed issue.260 As of this writing, the same strategy has been adopted by the

255 The number of individual Web users in the United States is now estimated in the millions. In January 1996, there were some 100,000 Web "sites" (locations of Web-based materials) worldwide, up from 23,500 in June 1995, 10,022 in December 1994. and 623 in December 1993. See generally Matthew Gray, Measuring the Growth of the Web. <http:/I www.mit.edu/people/mkgray/growth/> (May 8, 1996).

256 For explanations of hypertext, see generally Sven Birkerts, Hypertext: Of Mouse and Man, in The Gutenberg Elegies 151 (1994); M. Ethan Katsh, Hypertext: Constructing Cyberspace, in Katsh, supra note 248, at 195; George P. Landow, Hypertext: The Convergence of Contemporary Critical Theory and Technology 4 (1992) (describing hypertext as "a form of electronic text, a radically new information technology, and a mode of publication [which] denotes text composed of blocks of text ... and the electronic links that join them").

$257<$ http:/www.princeton.edu/ harnad/psyc.html> (May 8, 1996). Psycoloquy was in fact the first peer-reviewed, fully electronic scientific journal on the Internet. Ann Shumelda Okerson \& James J. O'Donnell, Introduction, in Scholarly Joumals at the Crossroads: A Subversive Proposal for Electronic Publishing 4 (Ann Shumelda Okerson \& James J. O'Donnell eds., 1995).

$258<$ http://jefferson.village.virginia.edu:80/pmc/> (May 8, 1996).

259 On the potential implications of this strategy for LEXIS and WESTLAIV, see Adrian Sherwood White, The Internet: Is It Curtains for Lexis-Nexis and Westlaw?, Legal Info. Alert, Apr. 1995, at 1, 1 (comparing resources and capabilities of on-line services with Internet, concluding that "the two big commercial legal networks can continue to breathe easily-at least for the moment").

260 E-mail from Will Sadler, Director of Internet Development, Center for ComputerAssisted Legal Instruction (CALI), to Bernard Hibbitts (May 13, 1996). Sadler put the Federal Communications Law Journal on-line with the cooperation of Fred Cate, Faculty 
Cardozo Arts and Entertainment Law Journal, 261 the Cornell Law Review, ${ }^{262}$ the Florida State Law Review, 263 the Hastings Women's Law Journal, ${ }^{264}$ the Indiana Journal of Global Legal Studies, ${ }^{265}$ the Villanova Law Review, 266 and the Villanova Environmental Law Journal. 267 Other such undertakings are forthcoming. ${ }^{268}$

By being offered on the Web, virtually all these journals make legal literature available to a national, international, and interdisciplinary public potentially much broader than that which has access to (and/or can afford) LEXIS or WESTLAW service. Also by virtue of their chosen platform, these print-derived electronic law reviews can take some advantage of multimedia and hypertext to facilitate access to footnotes and lead readers to other sources and types of documentation and legal information. Ultimately, however, these electronic versions of traditional, printed law reviews represent only limited progress over LEXIS and WESTLAW. Their format is necessarily driven (i.e. constrained) by the format of the print medium on which they are based. They cannot range too far from that (by, say, adding or changing information) without destroying their identities and a good part of their value. The fact that they constitute an additional burden on editorial staffs over and above that already imposed by their printed versions has also meant in some instances that far from coming out earlier and being distributed faster than their print equivalents, they actually come out much later, making them inferior to LEXIS and WESTLAW distribution at least in this respect. ${ }^{269}$

In 1995, four second-generation electronic law reviews emerged that had no print versions: the National Journal of Sexual Orientation

Advisor to the Journal. The current Web address for the Federal Communications Law Journal is <http://www.law.indiana.edu/fclj/fclj.html> (May 8, 1996).

261 Cardozo Arts and Entertainment Law Journal, <http://yu1.yu.edu/csl/journals/aclj> (May 8, 1996).

262 Cornell Law Review, <http://www.law.comell.edu/clr/clr.htm> (May 8, 1996).

263 Florida State Law Review, <http://law.fsu.edu/lawreview/index.html> (May 8, 1996).

264 Hastings Women's Law Journal, <http://www.uchastings.edu/womenslj/ womenslj.html> (May 8, 1996).

265 Indiana Journal of Global Legal Studies, <http:/www.law.indiana.edu/glsj/glsj.html> (May 8, 1996).

266 Villanova Law Review, <http:/www.law.vill.edu/vill.l.rev./> (May 8, 1996).

267 Villanova Environmental Law Journal, <http:/www.law.vill.edu/vill.envtl.1.j./> (May 8, 1996).

268 E.g., Journal of Gender and the Law, <http://sray.wcl.american.edu:80/pub/journals/ gender.htm> (July 29, 1996).

269 As of May 1996, for example, the Web-based edition of the Cornell Law Review was more than a year behind schedule due to the fact that maintaining it proved to be an unexpectedly onerous task. See e-mail from David Lodemore, Editor-in-Chief, Cornell Law Review, to Bernard Hibbitts (Dec. 8, 1995) (on file with author) (recounting problems keeping journal updated). 
Law (founded by Mary Sylla, a law student at the University of North Carolina), ${ }^{270}$ the Journal of Online Law (edited by Professor Trotter Hardy at the William \& Mary School of Law), ${ }^{271}$ the Richmond Journal of Law and Technology (edited by law students at the University of Richmond), 272 and the Michigan Telecommunications and Technology Law Review (jointly edited by students at the University of Michigan Law School and the University of Michigan Business School). ${ }^{273}$ These journals have a far greater potential to change and improve the way in which legal scholarship is distributed, accessed, and even done. In the first place, electronic law reviews are not grounded to a print format at all: articles appearing in them can be designed specifically for Internet distribution and access. They can theoretically take full advantage of multimedia and hypertext, not to mention the potential for updating, correction, and revision of published material that is inherent to a purely electronic medium. They can solicit and archive email from readers, thereby fostering academic dialogue. In addition, because they have far less physical and economic overhead than either print law reviews or their electronic equivalents (which have to bear the overhead both of themselves and their printed source), exclusively electronic law reviews are far less expensive to produce and distribute. Editors and managers do not have to pay printers for their services. In turn, "subscribers" do not have to pay for access. Furthermore, by virtue of their lesser overhead combined with their technological convenience, purely electronic law journals are relatively more likely (at least in the long run) to be controlled and edited by otherwise busy and individually impoverished law faculty. They therefore promise to address the "problem" of student editing. Finally, purely electronic

270 National Journal of Sexual Orientation Law, <http:/sunsite.unc.edu/gaylaw/> (May $8,1996)$.

271 Journal of Online Law, <http:/www.law.cornell.edu/jol/jol.table.html> (May 8, 1996).

- 272 Richmond Joumal of Law and Technology, <http://www.urich.edu/ joll/> May 8, 1996).

273 Michigan Telecommunications and Technology Law Review, <http:/I www.umich.edu/ mttlr/> (May 8, 1996). The foregoing list is limited to American publications only, and by definition does not include Cardozo Electronic Law Bulletin, <http:l www.gelso.unitn.it/card-adm/welcome.html> (May 8, 1996) (edited by law faculty at the University of Trento, Italy), $E$-Law, <http//wwwlib.murdoch.edu.au:8088/ecolln/type/jnls/ murdoch/elaw/elaw.html $>$ (May 8, 1996) (edited by law faculty at Murdoch University, Perth, Australia), Humboldt Forum Recht, <http:/www.rewi.hu-berlin/de/HFR/> (May 8. 1996) (edited by law students at Humboldt University Faculty of Law, Berlin, Germany). the Journal of Information Law and Technology, <http://elj.wanvick.ac.w/Jelj/jilt/> (May 8, 1996) (joint effort edited by faculty at universities of Warwick and Strathclyde in the United Kingdom), and the Web Journal of Current Legal Issues, <http:II www.newcastle.ac.uk/ nlawwww/> (May 8, 1996) (faculty-edited out of the University of Newcastle-upon-Tyre, England). 
law reviews are not bound to publish on a particular schedule or at a particular length. If they have a good article, they can distribute it immediately;274 if they have bad articles, they do not have to include them as necessary "filler."275 Under these conditions, authors need not be hung up by publication delays caused by the tardiness of other authors or problems with the printer, and readers need not be inundated with mediocre material.

In the context of these observations one might plausibly conclude that nirvana is nigh - that purely electronic law reviews provide the ultimate alternative for law professors (and others) suffering under the limitations of the present law review system. But such a conclusion would be premature and, I would argue, incorrect. Especially as presently constituted even purely electronic law reviews have serious problems, some of which might only be exacerbated were those reviews to become the foundation of a new structure of scholarly communication in law.

To begin, the number of purely electronic American-edited law reviews can currently be counted on the fingers of one hand, and there are few signs of the imminent and radical expansion of the genre. Moreover, all of the electronic law reviews now in operation are highly subject-specific, and three of them deal with technology itself. 276 In this context, relying on electronic law reviews alone would prevent most legal scholars from reaping the advantages of purely electronic publication for quite some time.

Additionally, the purely electronic law reviews that do exist are not taking full advantage of their medium.277 A comprehensive check of the current and back issues of the relevant legal journals reveals that as of this writing they have not made any use of multimedia, nor have they taken more than marginal advantage of hypertext. On a less obvious level, they are still releasing material in "issues" that ape the necessary periodicity of print publications. Some electronic law reviews are allowing their authors to take advantage of the more malleable nature of the electronic format by making changes to articles after publication, but thus far those changes cannot be made spontaneously by authors themselves; rather, the changes must first be sub-

274 Katsh, supra note 248 , at 44 .

275 See Wiggins, supra note 251, at 390 ("Another liberating aspect of e-journals is that there need not be any pressure to 'pad' an issue with a certain number of articles.").

276 See supra notes 271-73 and accompanying text.

277 This has been identified as a problem of e-journals in general. Rob Kling, Electronic Media and Legitimate Media in the Systems of Scholarly Communication, 11 Info. Soc'y 261 (1995). 
mitted to and then implemented by the reviews (creating an ironic structural bias against change). 278

More fundamentally, the purely electronic law journals are still burdened by problematic editorial structures. Three of America's existing purely electronic law reviews are student-edited. ${ }^{279}$ They therefore suffer from many of the same editorial limitations as traditional print-based student law reviews. The other electronic law journal is faculty-edited, ${ }^{280}$ but - as was emphasized earlier in another contextfew law faculty members have the time or the inclination to edit a journal and do it well. ${ }^{281}$ The number of faculty members having the time, the inclination, and the computer skills required to work comfortably in the new medium is even lower. While relatively less effort may be required to edit an electronic as opposed to a print publication (in part because printers are not involved), that effort still comes at a personal opportunity cost, which in turn imposes an implicit financial cost (in lost teaching and scholarship-production hours, not to mention staff support) on sponsoring institutions. Even if faculty members were able and could be persuaded to take on electronic editorial responsibilities en masse, it is highly likely that (as we saw in another context) ${ }^{282}$ the outlets for scholarly publication would be radically reduced, a development that could have a devastating impact on the careers of many legal scholars, not to mention on legal literature as a whole. Finally, faculty-edited electronic law journals are as vulnerable to intellectual capture and cooption as any print review. These eventualities could have serious intellectual consequences for the entire American legal community.

The last two general problems of current purely electronic law reviews-their failure to take full advantage of the new medium and their retention of traditional editorial structures-may be mutually reinforcing. Student law review editors have repeatedly been accused of being editorially conservative; 283 in this context, it is unlikely that they will unilaterally promote technologically radical forms of scholarship. Here, as elsewhere, their "credibility" in the legal and law re-

278 The reviews are doubtless shy about letting authors have direct access to reviews' servers. They are presumably also concemed that direct access would lead to loss of editorial control over the content of their publications. In the absence of direct access, however, authors may (incorrectly) regard some changes as more of a hassle than they are worth.

279 Michigan Telecommunications and Technology Law Review, supra note 273, National Journal of Sexual Orientation Law, supra note 270, and Richmond Joumal of Law and Technology, supra note 272.

280 Journal of Online Law, supra note 271.

281 See supra text accompanying note 216.

282 See supra note 220 and accompanying text.

283 See supra note 145 and accompanying text. 
view communities at large is at stake. Faculty editing is also an inherently conservative force. The process of peer review and selection, one of the "advantages" touted by faculty-edited e-journals, may-even in relatively forward-looking technological environments-encourage the publication of pieces that fit easily into generally accepted norms and conform with the ordinary stylistic expectations of editors and especially peer reviewers (who will not necessarily be as computer literate as the authors of articles in on-line law journals). On an even more basic level, student and faculty editors of the new electronic law reviews may ultimately shy away from experimentation for fear that experimenting would contribute to the failure of their initiatives (i.e., something that looks too different from print may not be accepted or cited). ${ }^{284}$ The greater the number of people involved in these initiatives as editors, peer reviewers, etc. (i.e., the more there is to lose), the more conservative a given review (electronic or otherwise) is likely to be. In this context, electronic law reviews may be very slow to realize their technological promise, a hesitancy which may significantly retard the progress of legal scholarship and, arguably, legal thought. ${ }^{285}$

In light of these critical limitations on both the actual and potential performance of purely electronic law journals in particular, I believe we can do better. Modern computer-mediated communications technology, notably the World Wide Web, offers us not only a new platform for legal scholarship, but also a radically new method for producing and distributing it which at a stroke could remove most of the editorial frustrations and administrative bottlenecks of the old print-based (and even the new electronically-based) law review system. In the next section of this Article $I$ identify this method and show how it might be used to redefine the practice and the process of American legal scholarship in the twenty-first century.

284 On the link between stylistic conservatism and professional acceptance of electronic journals, see Thomas J. DeLoughry, Effort to Provide Scholarly Journals by Computer Tries to Retain the Look and Feel of Printed Publications, Chron. Higher Educ., Apr. 7, 1993, at A19, A20 (discussing University of California at San Francisco's plans to develop electronic document delivery system and noting that "[t]he strategy behind the project ... is to make the computerized version of a journal as similar as possible to the paper edition so that faculty members are comfortable using it").

285 See Erik Jul, Electronic Publishing: Electronic Journals in a Print-on-Paper World, Computers in Libr., Feb. 1992, at 37, 38 ("Are electronic journals . . . adopting the conventions of print-on-paper journals in hopes of obtaining widespread acceptance among readers? Herein lies a danger. By imitating familiar formats, electronic journals may neglect fundamentally new possibilities of publishing and disseminating information made possible by computer and telecommunications technologies."). 


\section{IV}

\section{A Modest Proposal}

In the age of cyberspace, law professors can finally escape the straitjacket of the law reviews by publishing their own scholarship directly on the World Wide Web.

Far from being unprecedented, self-publishing is a time-honored, if hitherto problematic, part of the scholarly tradition. In the days before scholarly journals, scholars published their latest work in long letters to one another. ${ }^{286}$ Unfortunately, this was a labor-intensive process which permitted scholars to reach only one person at a time. In this context, many new ideas never received the broad exposure they deserved.

In the decades and centuries following the inauguration of the first printed scholarly journals in 1665,287 scholars were able to reach many more people with their ideas in a form that was both more legible and more stylistically consistent than any series of handwritten communiques. To secure these advantages, however, scholars had to surrender to editors a certain amount of control over how and even what information was disseminated. After all, print was a scarce material and cultural resource. As the quality and speed of print technology improved, as more and more scholars came to appreciate the professional advantages of print publication, and as they produced more and more scholarship, the journal editors who controlled access to print acquired more and more power over the scholarship selection and publishing process. Scholars had little choice but to tolerate this situation. Both sides "knew the score": without the approval and assistance of editors, scholars' work would not get printed, and therefore would remain essentially unknown.

In Part II of this Article, we saw that over time legal scholars have become increasingly displeased and frustrated with the law review system. Many law professors have variously accused law reviews of being too arbitrary, too slow, too error-prone, or too heavy-handed; they have blamed law reviews for running articles that are too conventional, too long, too heavily footnoted, or otherwise problematic. At

286 Bernard Houghton, Scientific Periodicals: Their Historical Development, Characteristics and Control 12 (1975). Books were deemed an inappropriate medium for new work: because they took too long to write and produce. Id.

287 The first scholarly journal appears to have been the Journal des scavans, published in January 1665. John Budd, Not What It Used to Be: Scholarly Communication Then and Now, in Scholarly Communication in an Electronic Environment: Issues for Research Libraries 1, 3 (Robert S. Martin ed., 1993). The first English-language scholarly joumal was the Philosophical Transactions of the Royal Society, published in London, England, in May of the same year. Id. at 3 n.5. 
bottom, all these accusations are complaints about editorial practices, the editorial process, or the material results of working within a given editorial system. The identity of the law review editors-students or faculty members-has done little to alter the fact of complaints; it has merely determined their details.

Today, however, new computer-mediated communications technologies, the more conservative manifestations of which I considered in Part III of this Article, provide law professors and other scholars with a way of breaking out of the editorial bind. For the first time in the history of legal scholarship, one medium in particular-the World Wide Web-provides a practical and attractive means by which law professors can take complete control of the production and dissemination of their own scholarly work.

The case for the self-publishing of legal scholarship on the Web is clear and strong. Law professors working at terminals with an Internet connection to the Web need not worry anymore about whether the subject of a piece is too esoteric, too doctrinal, too complicated, or even too impolitic for law review editors; we are free to write and publish on the topics of our choice. This freedom might provide a useful antidote to the substantive (conservative or trendy) sameness of the law reviews as they now exist. As our own electronic publishers, we need not tolerate the inaccuracies and indignities of amateur line-editing: we can present our own work exactly as we want it presented. As our own electronic publishers, we need not polish our articles on someone else's printing and production schedule; prior to publication, we can refine our pieces precisely when we want to (no more ridiculously or inconveniently short deadlines!). As our own electronic publishers, we need not cater to the technologically conservative expectations of peer reviewers or even of editors; we can "push the envelope," designing our presentations in what we regard as the most rhetorically effective manner. As our own electronic publishers, we need not endure months of frustrating or embarrassing delay while our papers are judged, peer-reviewed, or printed in formal legal journals; we can disseminate our articles instantly, as soon as we are satisfied with them, thereby maximizing the potential for timely and useful feedback. As our own electronic publishers, we need not turn our backs on our own work once it is printed without the benefit of revision, change, or correction; we can update or improve our own articles days, months, or even years after initial publication without going through an editorial middleman. As our own electronic publishers, we can even save money: if the practice of electronic selfpublishing becomes sufficiently generalized, our institutions will no longer have to spend hundreds of thousands of dollars paying for both 
the publication of our own (print or electronic) law reviews and our subscriptions to the law reviews of others.

While freeing legal scholars from inconvenient and occasionally oppressive editorial controls, electronic self-publishing also brings with it all the general advantages of Web technology (some of which I mentioned in passing while reviewing the advantages of electronic journal publication in Part III). Electronic self-publishing moreover gives legal scholars the advantages of Web publishing today-nowwithout having to wait (years perhaps) for certain print law journals to go on-line or for more purely electronic legal journals to be founded. On the Web, our ideas need no longer be circumscribed by the national or intradisciplinary circulation of particular law reviews; we can present our work to an international and interdisciplinary public. An article on war crimes, for instance, can be easily read by a legal scholar in Italy, or a sociologist at Berkeley. ${ }^{288}$ The latter possibility is an especially attractive prospect in this age of "interdisciplinary" legal scholarship:289 rather than hope that a law review article somehow leaks out into greater academia where it can have a truly interdisciplinary impact, legal scholarship can be made readily available to researchers from multiple fields who would otherwise never see a law review.

On the Web, we are no longer limited by the lineal nature of print or the physical limits of the article format; we can use the Web's hypertext capacity to set our ideas in a broader substantive context, incidentally allowing interested readers to follow particular threads of our analysis. 290 If we are discussing the Supreme Court's decision in Roe v. Wade, for instance, we can provide a hypertext link instantly connecting the reader to the full text of that decision.291 Not only is the use of hypertext likely to have explicit scholarly and informational

288 See supra note 177 and accompanying text.

289 By early August 1996-within six months of its initial release-the electronic version of this Article had to my knowledge (based on receipt of subsequent e-mail) already been read by law professors, lawyers, law students, information scientists, physicists, and anthropologists in the United States, legal scholars and law students in Germany, law professors and computer scientists in Australia and the United Kingdom, law librarians and sociologists in Canada, the director of a Comparative Law Center at a major Japanese university, and information technology specialists working for large American and French telecommunications companies. Over the same six-month period, the Article's counter registered more than 1500 reader "hits" in total.

290 In hypertext, "not only [will an author's] own works . . . be linked to each other, but a growing body of scholarly literature may be enmeshed in a net of links and connections that multiply the value of each item appreciably." Ann Shumelda Okerson \& James J. O'Donnell, Conclusion, in Scholarly Joumals, supra note 257, at 227.

291 LEXIS and WESTLAW have only very rudimentary hypertext capacities. LEXIS has a "Link" feature which enables readers to move from a case cite directly to the case itself; WESTLAW has a "Jump" feature which, inter alia, connects headnotes to case texts. 
benefits, but it may even encourage new and different ways to think about law consistent with hypertext's nonlineal and antiauthorial nature. ${ }^{292}$

On the Web, we no longer have to defer to the sensory limitations of the print medium; we can communicate our ideas and information with media and combinations of media that printed law reviews either cannot deal with or can deal with only with difficulty. For instance, an article on the Magna Carta might provide readers not only with the text of the famous thirteenth-century English charter, but also with a full color image of the manuscript in the British Library. Analogously, an article on the O.J. Simpson trial might include not only excerpts from the trial transcripts, but also pictures from the trial, audio clips of the legal arguments, and even video from the court proceedings. Far beyond making our scholarship more entertaining (a notinsignificant achievement in itself), such strategies promise to open up rich new vistas of legal academic inquiry. On the Web, senses, sounds, images, colors, movements, and performances can all come to center stage. Legal rhetoric, legal ritual, legal architecture, legal iconography, and other audio-visual practices and phenomena that are not easily captured or described in print will become more amenable to study and intelligent discussion. ${ }^{293}$ The pictorial and even the aural dimensions of legal documents which print has reduced to purely textual

292 For analyses of hypertext's nature and its implications from politics to pedagogy, see generally Landow, supra note 256; Hyper/Text/Theory (George P. Landow ed., 1994).

293 For examples of incipient efforts in these areas, all of which were to some extent handicapped by the limitations of the print medium, see Katherine Fischer Taylor, In the Theater of Criminal Justice: The Palais de Justice in Second Empire Paris at xxil (1993) (using black-and-white illustrations to help demonstrate "the way architecture participated in [the] spectacle [of criminal justice] and crystallized debates about justice as a reflection of society" in Second Empire Paris); Janet E. Ainsworth, In a Different Register: The Pragmatics of Powerlessness in Police Interrogation, 103 Yale L.J. 259 (1993) (describing how "direct speech" of men is more effective in invoking Miranda rights during police interrogation than "indirect" mode of expression characteristic of women and other marginalized groups); Milner S. Ball, The Play's the Thing: An Unscientific Reflection on Courts Under the Rubric of Theater, 28 Stan. L. Rev. 81 (1975) (describing theatrical clements of courtrooms and arguing that judicial proceedings are a type of theater); John $\mathrm{L}$. Barkai, Nonverbal Communication from the Other Side: Speaking Body Language, 27 San Diego L. Rev. 101 (1990) (suggesting that lawyers actively use body language to improve communication with clients); Ann M. Gill, The Oral Tradition of Gerry Spence in Pring v. Penthouse, 17 Sw. U. L. Rev. 693 (1988) (using trial transcript excerpts to recreate plaintiff attorney's narrative style); Bernard J. Hibbitts, "Coming to Our Senses": Communication and Legal Expression in Performance Cultures, 41 Emory L.J. 873 (1992) (arguing that "[1]ike all other types of meaning in [societies with little or no experience with writing], law and legal understandings are conveyed not only orally, but also in gesture, touch, scent, and flavor" and utilizing several black-and-white images of medieval manuscript illuminations depicting legal gestures). All of these endeavors would have been much more effective had they been augmented by the multimedia potential of the World Wide Web. 
artifacts (e.g., illuminated medieval legal manuscripts and even the Declaration of Independence, which recent research has revealed to have been composed for oral proclamation) ${ }^{294}$ will at long last be recovered and recreated. Individuals working in the legal system or otherwise involved in the legal process as judges, lawyers, clients, witnesses, or family members will be heard and seen for themselves in legal scholarship, instead of being (re-)presented and (mis)understood through the filter of words written on a page. Given the technological means, some of us might even choose to personally step before the microphone and/or the camera, creating multimedia Web "scholarship" that in its supratextual aspects might resemble "teaching," thereby breaking down the sharp, debilitating split that has long existed between these two forms of academic communication.

Finally, after we publish on the Web, we do not have to wait in our offices for someone to take the time to write to us or to make the psychological effort to call with comments of criticism or praise. The built-in electronic mail capacities of the Web allow and encourage our readers to provide meaningful and timely feedback to us at the touch of a button, ${ }^{295}$ comments which we can use as the basis of revision of the original article and/or append to the original document for the enlightenment and benefit of other readers and evaluators. ${ }^{296}$ Instead of being dead-on-arrival, every article we write on the Web can be a living creature, capable of interactivity, growth, and evolution.

The existence of a good prima facie case for the self-publishing of legal scholarship on the Web does not mean, however, that proponents of continuing the editorial status quo have no possible counterarguments. For instance, they might say that edited law reviews provide important quality control, without which the legal community would be flooded with substandard legal writing. There are at least three responses to this. First, most law professors who are inclined to publish are already writing at or near capacity; productivity would doubtless increase if professors did not have to spend time dealing

294 See, e.g., Jay Fliegelman, Declaring Independence: Jefferson, Natural Language, and the Culture of Performance 25 (1993) (arguing that marked pauses in Jefferson's original draft "call attention to the fact that the Declaration was written to be read aloud").

295 See Gates, supra note 252, at 143 ("For some reason people are less shy about sending e-mail than communicating on the phone or in person.").

296 See generally Stevan Hamad, Implementing Peer Review on the Net: Scientific Quality Control in Scholarly Electronic Journals, in Scholarly Publishing: The Electronic Frontier 103 (Robin P. Peek \& Gregory B. Newby eds., 1996); Andrew M. Odlyzko, Tragic Loss or Good Riddance? The Impending Demise of Traditional Scholarly Journals, in Scholarly Publishing, supra, at 91, 96-98. E-mailed comments on Version 1.0 of this Article (with my responses) have been collected at <http://www.law.pitt.edu/hibbitts/readers.htm> (May 8, 1996). 
with law review editors and their rewrites, but a quantum increase in the pages of writing generated is unlikely. Second, "flooding" by selfpublished electronic papers is not a problem in the same sense that flooding by printed papers is. In an electronic system, no one is going to be buried in paper who does not want to be. Given electronic searching, no one has to flip laboriously through pages and pages of unwanted articles to get to the one he or she wants to find. The Web could in fact absorb a gigantic number of scholarly contributions without individual legal scholars or researchers becoming inconvenienced by or even conscious of such a development.297 Third, "quality control" would not suffer under the self-publishing proposal. We have already seen that the current law review system operates with minimal quality control in the generally accepted ("peer review") sense of that term: there are still very few faculty-edited law journals, and it is at least questionable whether the second- and third-year editors of the student-run reviews can consistently make accurate qualitative (as opposed to institutionally, reputationally, or stylistically related) judgments about submissions other than those dealing with the most familiar subjects or offering the most familiar (e.g. doctrinal) brands of legal analysis. In this context the elimination of what now passes for "quality control" might actually be an improvement.

The point is moot, however, for Web self-publishing and signifcant, professorially undertaken quality control are in fact highly compatible. To a large extent, quality control in a self-publishing environment will be self-imposed. Individual legal scholars, knowing that their work will be presented to the world in exactly the form in which they leave it, will be strongly encouraged to carefully review their arguments, their facts, their texts, and their citations in circumstances where they can no longer leave those tasks to student editors. Those tasks, moreover, are not as daunting as they might initially appear. Some could be delegated to personal research assistants who in practice might be more capable and in some ways more responsible

297 [E]lectronic publication presents few disincentives to publishing large amounts of material. An electronic literary journal has no reason to decline to run a competent 10,000-word article about an obscure author simply because it is of interest only to a few subspecialists, because no one else is likely to call it up anyway. An electronic newsmagazine article on the civil war in Somalia can include forty columns of background material as a kind of sidebar interested readers can open by clicking an icon. ... In the course of things, then, electronic [forums] will become more inclusive, on the reasonable assumption that readers can ignore irrelevant information much more easily in electronic formats than if it were included in a 400-page volume stuffed in their mailbox every month.

Geoffrey Nunberg, The Places of Books in the Age of Electronic Reproduction, 42 Representations 13,23 (1993). 
than particular student editors at other law schools (the former, unlike the latter, would notably be unable to set their errors in print); other tasks could be discharged with the aid of computerized spell-checkers, grammar-checkers, and even citation-form-checkers which are becoming ever more reliable. For the same purpose of avoiding public embarrassment (as well as to simply improve their scholarly products), many law professors will doubtless choose to continue the current practice of informally circulating drafts to friends and colleagues, thereby ensuring to themselves the benefit of prepublication feedback. Critical quality control might also be provided after the fact by reader comments that the new technology could "attach" to any given self-published article; ${ }^{298}$ positive comments would probably make an article more significant, while negative comments (or no comments) would probably encourage its marginalization. In effect, this would be a new and improved form of (post-hoc) peer review, where the "peers" would be individuals sufficiently interested and informed about the article's subject matter to have read the article voluntarily, and where the reviews would rate an article without (as in the current system) forcing its perhaps premature or unfortunate suppression if the reviewers' verdicts were negative. ${ }^{299}$ As a complementary strategy, individual law faculties might even compile lists of (and links to) recommended articles on their own Web "home pages," thereby providing a further measure of quality-based bibliographic guidance for colleagues.

A variant of the "no quality control" argument might be that selfpublishing on the Web would destroy the existing technical standards for law review writing which have been created implicitly and explicitly by generations of print law review editors and which are now being carried on (with some adjustments) by their successors working in electronic formats. This is theoretically possible, but probably not likely in the short term: self-published scholars (like the editors of purely electronic law reviews, albeit to a lesser extent) have at least some incentive to adhere to prevailing conventions so as to render their work acceptable. Even assuming that existing standards did collapse, however, would that be such a bad thing? The historical record of law review criticism-going back to Fred Rodell and beyondwould suggest not. The freedom that would come with Web selfpublishing could eventually prompt a lot of fresh air to blow across a fairly arid stylistic terrain. New formats would appear; new types of

298 See supra note 296 and accompanying text.

299 A form of this post-hoc peer review already exists in some print journals in other disciplines, such as Current Anthropology and Behavioral and Brain Sciences, where published pieces are routinely followed by several reviews, and, ultimately, the author's reply. 
presentation would be tried. But of course style is not all that is at stake here. Less obviously, but perhaps more importantly, so is the Bluebook. The Bluebook, however, has many limitations and critics already..$^{300}$ Its demise, or at least its decline, would not be disastrous so long as legal academics make an honest effort to make their references understood, which is ultimately in their own interest. Indeed, freedom from Bluebook conventions would likely make some citations (especially to foreign and nonlegal materials) more rather than less intelligible. ${ }^{301}$ Proponents of Web self-publishing might even argue that the Bluebook is largely irrelevant in a Web environment: as that environment develops and information is added to it, footnotes and references as we now know them are likely (in many, if not in all instances) to be replaced by direct hypertext links to the cited material. In other words, instead of dropping a conventionalized footnote (in appropriate Bluebook style) to, say, Stephen Shiffrin's article $R a$ cist Speech, Outsider Jurisprudence and the Meaning of America in the March 1994 issue of the Cornell Law Review, a Web-based paper would link directly to that article (and perhaps, given an existing internal "anchor," even to the relevant paragraph, an improvement over current page-based citation). ${ }^{302}$ No footnote and no Bluebook required.

A second major argument that might be advanced against Web publishing by defenders of edited law reviews is that only journals (be they in print or electronic form) are capable of efficiently bringing legal scholarship to the attention of legal readers; in this analysis, independently published legal scholarship would be lost in a sea of information. At the moment, these assertions have some truth to them. However, they overlook two important points. First, printed scholarship (even when produced in journal form) is itself often lost in a sea of (printed) information, despite the best efforts of the indexing services. Second, without a physical form or fixed shelf space, the current electronic law journals are particularly hard to find unless you know exactly what to look for. ${ }^{303}$ Together, these points mean that edited law reviews themselves cannot guarantee that scholars will find readers, or that readers will find scholars.

300 See, e.g., supra note 197.

301 For complaints about how the Bluebook often mangles references to these sources, see Conard, supra note 190, at 2 (contrasting nonlaw journal citation forms with "confusing[ ]" law review citation forms).

302 See generally Okerson \& O'Donnell, supra note 257, at 227.

303 I.e., their names, or a comprehensive listing, such as that provided by FindLaw at $<$ http:/www.findlaw.com/03journals/fulltext.html> (May 8, 1996). 
The potential problem of "unfindable self-published legal scholarship" could be solved, however, if a legal academic institutionmost obviously, the AALS-created, publicized, and maintained a Web site to which all law professors could submit or hypertextually "link" their scholarly work. This site would be somewhat similar to an electronic archive insofar as scholars and others would access it to look for articles. At the same time, it could potentially be different insofar as articles would not have to be actually stored there (although some could be), but rather could be stored by individuals on their own individual or institutional home pages (in which case the central site would serve as a "pointer"). Such a central site, made electronically searchable by category and keyword, could provide a legal researcher with a convenient listing of an individual scholar's writings, articles citing a particular case, articles in a particular field, etc. There is no technological reason why such a site could not be supplemented by an electronic notification service which could inform individuals interested in particular material whenever a new article relevant to them was submitted to or linked to the site, or when an existing article they had previously accessed was updated, corrected, or otherwise revised. The result would be a system that would be more accurate, more accessible, and more flexible than anything that exists today in the context of formal periodical publication. If an academic institution were to construct an electronic archive of self-published scholarship, it also could set (and enforce) minimal standards of access and conduct to ensure that only authorized individuals (e.g., lawyers and academics) submit materials to or register materials with the archive, and that "flaming" or other objectionable behavior does not disrupt the necessary decorum of academic debate. ${ }^{304}$ It might also enter into cooperative agreements with other institutions fulfilling similar tasks in other disciplines so as to facilitate the free exchange of scholarly information.

At least some proponents of edited law reviews are likely to raise a third argument against Web publishing, pointing out that only a small fraction of legal scholars are on the Web-or even on the Internet in general-and so electronic self-publishing is not a practicable alternative, there being too few electronic writers and/or too few electronic readers to make it academically advantageous. The argument is problematic, however, insofar as there is every indication that more

304 "Flaming" is the practice of sending abusive personal messages over the Internet. An academic institution supervising an archive of electronic scholarship could police flaming by refusing to post the "filame" and/or censuring the offending party (in extreme cases, perhaps by refusing him/her access to the archive for deposit of his/her own scholarly work). 
and more American law professors and lawyers are gaining Web access as their law schools and law firms come on-line in increasing numbers. ${ }^{305}$ The group of potential readers for (and writers of) selfpublished Web scholarship is therefore growing all the time, and growing rapidly. In this context, the original point becomes somewhat akin to a hypothetical argument that might have been made (with unfortunate long-term results) against printing scholarship in the early days of printed scholarly journals: "Let's stick to writing letters because not all scholars have access to printing facilities or printed materials."

A variant of this argument would be that even if law professors are coming on-line, it is too technically difficult for most of them to publish on the Internet directly. Once there might have been something to be said for this argument, but given recent developments in Web publishing, it should not be taken that seriously. In the first place, the Web's publishing language, Hypertext Markup Language (HTML), can be learned in a few hours (it is much easier, in fact, than the other computer languages such as Fortran, Basic, $\mathrm{C}$, etc., that some of us were introduced to in secondary school or college). Once one learns the rudiments of HTML, materials that a law professor has already put into a computer in a standard word-processing format (e.g., Microsoft Word, Word Perfect) can be made HTML-compatible almost instantly, without even having to be retyped. In other words, with only a little more effort, the rewards of writing one's scholarship on a computer to begin with (which virtually all of us do these days) can be radically increased. In the second place, a wide range of software packages known as HTML "editors" is now available which enables one to create Web documents easily and quickly without ever learning HTML itself. ${ }^{306}$

Fourth, traditionalists preferring edited law reviews in general and printed law reviews in particular might argue that a system of selfpublishing on the Web would incidentally condemn legal academics to the physically uncomfortable fate of having to read an increasing amount of new legal scholarship on computers. The visual limitations of computer screens are well known, ${ }^{307}$ as is the inconvenience attend-

305 See, e.g., Hadrian R. Katz, Internet Use Spreads Through 'World Wide Web', Nat'! L.J., Jan. 30, 1995, at C10 (discussing accessibility of Internet and World Wide Web and noting that various law firms, universities, and other institutions have set up Web servers containing legal information or links to legally oriented materials).

306 E.g., HotMetal, HotDog.

307 See A. Dillon et al., Reading from Paper versus Reading from Screen, 31 Computer J. 457, 463 (1988) (surveying various experiments and concluding that "reading from computer screens may be slower and sometimes less accurate than reading from paper" and that "[u]ntil screen standards are raised sufficiently these differences are likely to remain"). 
ant upon having to sit down at a terminal (as opposed to your favorite armchair) in order to read a computer-based work. ${ }^{30 s}$ While granting both these points under current technological circumstances, multichrome screens with greater resolution and less glare have been and are being developed that go a long way to solving the first problem. ${ }^{309}$ Miniaturization is already helping to make computer technology more portable (witness laptops), pointing the way towards a solution for the second. 310 Finally, the fact that a legal article or some other document is initially published on-line does not mean that it cannot be accessed or used by a would-be reader in print-all one has to do is download the relevant piece to a printer, whereupon it assumes all the familiar, even cozy qualities of the traditional printed format.

In a related vein, traditionalists might argue that computerpublished articles are less aesthetically pleasing than print pieces, and that therefore self-published scholarship will look prohibitively worse than its print equivalent. This might have been true once, but today it is at the very least debatable. With the aid of popular "browsers" (Mosaic and Netscape in particular), the Web is an increasingly reader-friendly visual environment; it is, in fact, much more legible than LEXIS or WESTLAW, substituting traditional Roman-style letters for harsh, "computerish" typefaces. On standard (thirteen- to fifteen-inch) computer screens, moreover, the letters and words of Web documents generally appear much larger than they do in most printed law reviews.

A fifth argument against self-publishing on the Web might focus on the likelihood that-if the strategy proved attractive and successful-it would deprive students in particular of the benefits of editing a law review. The problems with this argument should already be apparent. As we saw in Part II of this Article, many law professors and even some law students have argued that the educational value that students derive from the editing exercise is at least dubious. ${ }^{311}$ As a result, there may be little to be lost by the decline and potentially the fall of the law review as an institution. Indeed, there may be some-

308 See The Limitations of Electronic Journals, $38 \mathrm{~J}$. Reading 405, 405 (1995) (noting in recent survey that "scholars reported considerable eye strain and the fatigue of sitting in one position" and commenting that "an electronic journal would be OK only if they had a computer terminal always right at hand").

309 See Gates, supra note 252, at 72 (predicting that "[b]oth TV screens and PC screens will continue to improve ... in quality").

310 Id. at 113 (predicting that "[u]ltimately, incremental improvements in computer and screen technology will give us a lightweight, universal electronic book, or "e-book," which will approximate today's paper book" and which will be capable of "show[ing] highresolution text, pictures, and video").

311 See supra notes $174-76$ and accompanying text. 
thing to be gained: if law review work were largely eliminated, students would have more time for classes, studying, and getting the benefits of a formal legal education. Any "missed opportunity" for student training in legal research and writing that might be caused by the elimination of the law review could probably be more than counterbalanced by instituting upper-level legal writing programs and/or working with individual students to make their own papers publishable. Even apart from this, direct professorial publishing on the Web would not in itself prevent law students from continuing to publish a law review if they or others deemed the educational experience sufficiently useful and important. Law students might, for instance, turn to publishing print or electronic law journals for themselves, using them as vehicles for, say, circulating the best student papers from their own law schools to the legal community at large. Institutionally, this would probably be much better than allowing unrestricted student legal publication in an AALS-supervised archive.

Of course, moving towards self-publishing of legal scholarship on the Web would equally deprive faculty editors and peer reviewers of their roles in the current law review system. Here too there would seem to be an ostensible loss: editing and reviewing may provide at least some law professors with professional stimulation and connections. In the long run, however, the same individuals would likely benefit from the change. With no law review to run and no submissions to review, law professors could (and perhaps would be prompted to) get on with their own writing, which after all is the primary route to professional and institutional advancement in the legal academy. They could save time; their institutions would save money. If erstwhile reviewers really did want to spend time telling others what they thought of their work, that option would still be available to them via what I earlier described as "post-hoc" peer review; indeed, this peer review, for the peer reviewers, would be less a form of peer review in the private, limited sense of the term, than it would (by definition) be a publication in itself. In this context, peer reviewers might finally have their cake and eat it too (i.e., do peer review and get formal scholarly credit for doing that), which might result in a better quality of criticism.

A sixth, and perhaps the most frank argument that defenders of edited law reviews might make against Web self-publishing would focus on the loss of incidental prestige to authors, editors, and institutions that would likely be caused by the adoption of such a strategy. If legal scholars published themselves, they would be deprived of the "halo effect" of a "good" placement in a "reputable" law review. If legal scholars published themselves, the publishing institutions (not to 
mention the editors of the institutions' reviews) would moreover be unable to claim the benefit of any reflected glory. But these points, even if powerful, 312 are surely specious. "Halo effects" are intellectually suspect-surely serious scholars would agree that scholarly articles should ultimately be evaluated on their own merits, rather than according to the prestige of the law review in which they appear, especially when the law reviews exercise little if any true quality control. In this context, eliminating the "halo effect" of placement would remove a significant temptation in the way of free and fair evaluation of scholarship, while at the same time (re)focusing the attention of law professors on doing their scholarly work for its own sake, rather than playing the placement game. ${ }^{313}$ Furthermore, self-publishing would not end all prestige benefits for either law professors or their institutions. Under the new system, professors would gain prestige from the positive, reasoned electronic comments of their colleagues (doubtless an improvement over the implicit endorsement of students or even the publicly unarticulated judgments of anonymous peer reviewers), while law schools would presumably continue to derive status from the published product of their faculty (doubtless more deserved and substantial than the faint reflected glory derived from publishing the works of professors from elsewhere).

Finally, supporters of edited law reviews (either in print or electronic form) might just throw up their hands at the notion of professorial self-publishing on the Web, saying, "the whole idea's just crazy; it's science-fiction; it would never work." But the general idea (or something very much like it) has already been implemented by individual scholars all over the world. It has become standard procedure in at least one discipline and is making practical headway in several

312 The continuing academic allure of the "halo effect" was recently demonstrated at an international mathematics conference when a Canadian mathematics professor unsuccessfully tried to persuade his colleagues to publish electronically all 135 papers submitted rather than waiting for traditional publication. The professor later commented with some chagrin, "I think [my proposal] failed because people like this kind of ranking. That's also one of the reasons I'm so excited about [electronic publishing], because of the challenge to these elitist traditions." Quoted in Barry Ries \& Peggy Berkowitz, The Electronic Journal: Has Its Time Come?, U. Aff., Aug.-Sept. 1995, at 10, 11.

313 See McDowell, supra note 142, at 270-77 (discussing "scholarship game" and how to control it in interest of producing truly valuable legal research and writing). In some instances, "halo effects" can be not only distortive, but destructive. On more than one occasion candidates for tenure promotion (not to mention members of their respective law faculties) have assumed that good placements favored and perhaps guaranteed success, only to have their hopes dashed by disappointing external reviews (indicating, not incidentally, that the professional reviewers disagreed with the quality judgments of the student editors). 
others. Highly credible commentators and committees have lately recommended it for even wider academic application.

The present argument for the self-publication of legal scholarship on the Web would not be complete without some description of each of these initiatives. Very soon after the World Wide Web was developed (and with increasing frequency after the release of Mosaic and Netscape), individual academics in a variety of different disciplines realized its enormous professional and scholarly potential. Without waiting for their colleagues to "catch up" or for their academic associations to formally endorse their actions, scholars in such fields as computer science, mathematics, physics, public health, classics, media theory, and even law began putting portions of their work directly online for the world to see. Some of these materials were electronic "post-prints" of papers that had already been formally published elsewhere. ${ }^{314}$ Others were abstracts of those papers. ${ }^{315}$ A few enterprising scholars even took the next logical step and began to put "unpublished" papers on-line, some with a view to getting feedback prior to seeking formal publication in traditional media, others under the assumption that distributing a piece on the Web made other publication redundant. ${ }^{316}$ These practices are becoming more and more common as more and more academics enter the Web and realize what it can do for them and for their ideas.

Some academic disciplines have nonetheless made more organized progress in the direction of electronic self-publication than have others. In the early 1990s, physics took the lead in this respect and has kept it ever since. In May 1991, David Mermin, a disgruntled but prescient academic columnist for Physics Today, openly declared that "[t]he time is overdue to abolish journals and reorganize the way we do business." 317 He proposed that physicists e-mail their work to a "central clearinghouse" which would then post that work on an electronic bulletin board for perusal and downloading by others as necessary. ${ }^{318}$ Physicist Paul Ginsparg of the Los Alamos National

314 E.g., Ethan Katsh, Rights, Camera, Action: Cyberspatial Settings and the First Amendment, <http:/www-unix.oit.umass.edu/ eleclaw/ylj.html> (May 8, 1996), originally published at 1 Yale L.J. 1681 (1995).

315 E.g., Bernard J. Hibbitts, Making Sense of Metaphors: Visuality, Aurality and the Reconfiguration of American Discourse, <http://www.law.pitt.edu/hibbitts/makesen.htm> (May 8, 1996), originally published at 16 Cardozo L. Rev. 229 (1994).

316 E.g., James J. O'Donnell, The Pragmatics of the New: Trithemius, McLuhan, Cassioderus, <http://ccat.sas.upenn.edu/jod/sanmarino.html> (May 8, 1996) (Classics, University of Pennsylvania).

317 N. David Mermin, Publishing in Computopia, Physics Today, May 1991, at 9, 9.

318 Id. Mermin was not, however, the first academic to come up with this general idea. In 1989, Sharon Rogers and Charlene Hurt, library directors at George Washington and George Mason universities, respectively, proposed the creation of a "Scholarly Communi- 
Laboratory took concrete action in August of the same year. ${ }^{319}$ Frustrated by the prevailing system of scholarly communication in highenergy physics in particular, where-as elsewhere in the sciencesdelays and difficulties inherent in the existing system of peer-reviewed journals had stimulated the circulation of expensive, self-published, paper "preprints," he created what he called a "preprint electronic archive" to which individual physicists could send electronic versions of their preprints prior to formal publication. ${ }^{320}$ As constructed, this fully automated archive was active as well as passive: not only did it make papers available for access by e-mail, File Transfer Protocol (FTP), and (eventually) World Wide Web, but it used e-mail to notify "subscribers" of new submissions. ${ }^{321}$ Ginsparg's system has since become so successful that in high-energy physics, the electronic preprint archive has not only replaced the practice of circulating paper preprints, but has largely superseded the formal printed journals as "primary disseminators of research information."322 Ginsparg's archiving software has meanwhile been applied to some twenty-five other research disciplines ranging from other areas of physics (astrophysics, condensed matter theory, quantum physics, chemical physics, etc.) to mathematics, economics, computational linguistics, and even oceanic sciences. 323 A similar program has recently been used in Japan to create an international database of self-published preprints in philosophy. ${ }^{324}$

In several major fields where a lesser amount of practical progress has been made, electronic self-publication of scholarship has lately come highly recommended. For instance, in May 1995, a team of public health professionals and information specialists (including managers at AT\&T and NASA) headed by Ron LaPorte of the University of Pittsburgh Graduate School of Public Health proposed a

cation System" which would electronically archive submitted scholarly articles for retrieval and comment. Sharon J. Rogers \& Charlene S. Hurt, How Scholarly Communication Should Work in the 21st Century, Chron. Higher Educ., Oct. 18, 1989, at AS6; see also Stevan Harnad, Scholarly Skywriting and the Prepublication Continuum of Scientific Inquiry, 1 Psychol. Sci. 342, 342 (1990); Richard Lanham, The Electronic Word: Literary Study and the Digital Revolution, 20 New Literary Hist. 265 (1989).

319 Paul Ginsparg, First Steps Toward Electronic Research Communication, <http:/I xxx.lanl.gov/ftp/hep-th/papers/macros/blurb.tex> (May 8, 1996).

$320 \mathrm{Id}$.

321 E-mail from Paul Ginsparg to Paul Southworth, reprinted in Scholarly Journals, supra note 257 , at 14 .

322 Id. at 36.

323 Ginsparg, supra note 319.

324 The International Philosophical Preprint Exchange, <http:/phil-preprints.l.chiba-u. ac.jp/IPPE.html> (May 8, 1996) (service provided by Department of Philosophy, Chiba University). 
Ginsparg-style system of electronic self-publication for the health sciences. In an article in the British Medical Journal provocatively entitled The Death of Biomedical Journals, LaPorte and his team detailed the editorial and financial limitations of the current biomedical periodical structure. ${ }^{325}$ They described their work on a "Global Health Information Server" (part of the Global Health Network) that would facilitate distribution and exchange of biomedical research by eliminating journals and preliminary peer review in favor of electronic archiving of revisable, self-published papers with peer review provided post hoc by interested readers. ${ }^{326}$ Issuing a clarion call for radical, liberating change, LaPorte concluded, "[i]t is time that scientists begin to take control of their research communication."327 LaPorte's proposal prompted a spirited response from the editors of the prestigious New England Journal of Medicine, who argued that the lack of preliminary peer review in his system not only threatened to undermine "time-tested traditions," but might potentially cost lives or cause physical harm to patients whose doctors read inadequately reviewed literature. ${ }^{328}$ At the same time, the Journal moved to preemptively stifle any scholarly migration to the Global Health Information Server or other similar electronic archive by issuing an ill-disguised threat: "[P]osting a manuscript ... on a host computer to which anyone on the Internet can gain access will constitute prior publication" rendering an article ineligible for publication by the Journal itself. ${ }^{329}$ Even in this context, LaPorte's program has garnered significant support, both nationally and internationally. To the extent that it remains controversial, its greatest problems would by definition not be encountered in legal scholarship, which neither has an entrenched peerreview system to lose nor runs the risk of causing death or physical harm if quality control becomes problematic (although I have already argued that post-hoc peer review in particular would make such a development unlikely).

Systems or proposals for reform of scholarly communication that make sense in one or more disciplines admittedly may not be automatically appropriate for another having significantly different traditions, characteristics, or sensibilities. The existence of the paper preprint system in high-energy physics, for instance, made it easier to

325 Ronald E. LaPorte et al., The Death of Biomedical Journals, 310 Brit. Med. J. 1387 (1995).

326 Id. at $1387-89$.

327 Id. at 1390.

328 Jerome P. Kassirer, M.D. \& Marcia Angell, M.D., The Internet and the Journal, 332 New Eng. J. Med. 1709 (1995).

329 Id. at 1709. 
create an electronic archive of self-published scholarship existing outside the traditional bounds of the printed physics journals. That said, however, this Article has demonstrated that internal professional circumstances-and not just the abstract existence of a technologymake Web self-publishing a particularly attractive option for the legal academy. The potential of electronic self-publication in law, if not its specific application to the World Wide Web, has notably been recognized by at least one group of legal information specialists. In 1993, the interim report of a joint committee established by the University of Dayton School of Law and Mead Data Central to study the role and potential of computer technology in legal education suggested (apparently inspired by some of the musings of Cornell law professor Peter Martin) that, in the future,

[1] aw reviews may be replaced by direct access databases to which faculty contribute their scholarly work. . . . "Direct" publishing of scholarly material ... provides a fast and efficient arena for scholarly debate and critique. This shift away from hard copy to on-line availability raises a number of questions about the future role of student edited law reviews. ${ }^{330}$

Not having been specifically charged with the task of reexamining legal scholarship, the committee made its comments only in passing, but they nonetheless lend credence to the present proposal.

The self-publishing of legal scholarship on the Web might not be altogether without its own difficulties and challenges (e.g., downloading delays and connectivity disruptions, problems typical of stillevolving technology), but the theoretical and practical analysis offered here suggests that in the context of the multiple problems plaguing the contemporary law review system, the professional and intellectual benefits of such a scheme would be well worth the risks. The question therefore becomes, what can the members of the American legal academy-professors, administrators, leaders of academic organizations, and even law review editors-do to make this "modest proposal" a reality?

\section{Conclusion: What is to be Done?}

This Article has comprehensively reassessed the institution of the law review from the perspective of the present age of cyberspace. In Part I, I began this reassessment by showing how the law review first developed from the interaction of improved print technology with the institutional circumstances of American law schools in the late nine-

330 The University of Dayton Sch. of Law and Mead Data Central Joint Comm. to Study Computer Technology in Legal Educ., Interim Report, at 33 (Aug. 1993). 
teenth and early twentieth centuries. In Part II, I traced the course that criticism of the law review system has taken over the years, relating the shifting pattern and growing intensity of the criticisms to ongoing changes in the legal academy. In Part III, I showed how new computer-mediated communications technologies embodied in LEXIS, WESTLAW, and the various electronic law journals have subtly altered (and have arguably improved) the way in which legal scholarship is distributed, accessed, and used; at the same time, I emphasized that those formats have neither succeeded in curing the fundamental deficiencies of the law review system nor realized their own technological potential. In Part IV of this Article, I argued that legal scholars simultaneously might avoid many of the pitfalls and problems traditionally associated with the law reviews, might seize exciting new professional and intellectual opportunities, and might take full advantage of the new computer technology by publishing their own scholarship on the Internet platform known as the World Wide Web.

Given the range of benefits that self-publication of legal scholarship on the Web would bestow on legal scholars and the legal community as a whole, it is theoretically possible that the practice will develop spontaneously (as, to some extent, it already has), ${ }^{331}$ slowly gaining popularity until it becomes the scholarly norm. There are, however, steps that can be taken to accelerate and enrich this otherwise gradual process.

The precise nature of these steps depends in large part on who is taking them. Individual law professors, for instance, can promote Web-based legal publishing by putting their own papers on-line as soon as possible. Individuals who retain copyright to their published pieces can put their existing scholarship on-line immediately. Those who have granted copyright to law reviews can either negotiate with those reviews to regain copyright so as to allow on-line publication of their full texts, or, at the very least, they can post abstracts of their published pieces. Those in the process of writing legal scholarship might consider putting that scholarship on-line themselves as soon as it is completed to their satisfaction. This need not preclude later publication of their work in a printed or electronic law journal332-indeed, on-line release could be perfectly compatible with that insofar as Web publication would probably elicit feedback that would improve the printed product, and, moreover, would allow scholars to

331 See supra notes $314-16$ and accompanying text.

332 One might actually lead to the other; Web posting of the present piece led within a couple of weeks to four unsolicited offers to publish from accredited law reviews. 
reach what are now two relatively distinct audiences. ${ }^{333}$ Over the years, however, legal scholars will probably discover (as an increasing number of scholars in other fields have already found) that a twotrack publication system is awkward, unstable, and ultimately selfdefeating. Writers used to working on the Web will eventually find the absolute or relative fixity of their formally published products frustrating, and in order to meet criticism, maintain the integrity, and/ or extend the shelf-life of those products will likely opt to revise their Web-based versions after (as well as before) formal publication. Readers will inevitably be drawn to the most up-to-date version of any given article, and will therefore stop using or referring to articles in their formally published forms once those have been superseded by electronic revision. Together, these developments will make law review publication increasingly unattractive (indeed, unnecessary) as a professional option.

Law deans and law faculties as a whole, meanwhile, should encourage or at least recognize the scholarly value of self-published, electronic legal scholarship. If they do not endorse or support the practice, preferring publication through the old, established channels of the law reviews, their inaction will make Web publication impractical or at least unattractive for precisely those members of the legal professoriate who are otherwise most likely to take advantage of and gain from it: younger, more computer-literate legal scholars under significant pressure to publish in order to obtain tenure and promotion. On the other hand, if they intervene positively by declaration or even by example, deans and senior scholars will encourage their younger and more ambitious faculty colleagues to unprecedented heights of productivity and, very likely, creativity.

As I indicated in the previous section of this Article, the AALS might play a highly constructive-indeed, a critical-part in any movement towards Web-based self-publishing by exploring the possibilities for establishing an automated, but supervised, Web site which would archive and link the new corpus of self-published legal scholar-

333 Feedback from the release of the electronic version of this Article has benefitted its present print version, although more substantial revision will have to await the next electronic edition. Legal scholars interested in preserving their legal authority to unilaterally maintain, update, and revise the electronic version(s) of any given article after print publication might consider amending the standard law review copyright-transfer agreement by inserting a term expressly reserving to themselves all rights to publish, transmit, and modify the article in electronic form (with the exception of LEXIS/WESTLAW distribution, which is more conveniently left to the reviews themselves). Such a term was included in the copyright agreement governing the publication of this Article. See supra note 
ship. ${ }^{334}$ At least initially, it might be worthwhile to explore the potential applicability to law of some variation of Paul Ginsparg's archival physics software (which, it should be recalled, already has been successfully exported into other disciplinary fields). If the AALS is unwilling or unable to take the general initiative, a single American law school might consider providing such a site as a service to both the legal professoriate and the wider legal community. The cost of such an undertaking would be well within the means of even a non-elite school, given a preexisting Web connection: Ginsparg's own experiment was undertaken on a shoestring (if never formally established) budget, covering a few hours of programming labor plus hard disk space on an existing machine (valued in 1991 at under \$5000) which ran and continued to run other programs. ${ }^{335} \mathrm{~A}$ small investment here could have a very big payoff: given the critical position the sitesponsoring law school would likely come to occupy in the broader constellation of American legal scholarship and information, such a school might make a considerable name for itself in the age of cyberspace, just as Harvard cinched its reputation in the heyday of cheap print by inaugurating its law review. The institutional boost to the site-sponsoring school would be that much greater if its faculty, like the Harvard faculty in the early years of the Harvard Law Review, made a special point of publishing or (in the case of already-printed

334 The AALS might profitably take the advice of Tim Berners-Lee, the principal developer of the World Wide Web:

Put a cheerful front page to the archive: put some graphics in at the top to encourage readers. Let the thing run with a few gigabytes of disk space, and see whether society responds. You will have to jump start it probably with an injection of existing archives of papers, or pointers to them: otherwise, you will never get a critical product of readership and information base.

E-mail from Tim Berners-Lee to Virginia Polytechnic Institute Electronic Journals List (July 5, 1994), reprinted in Scholarly Journals, supra note 257, at 37-38. The AALS might also keep chronological track of submissions to such an archive, enabling legal scholars to make and prove priority claims as appropriate. AALS might even provide a running ratings system for archived articles ("four stars" or perhaps "two thumbs up") based on the reader comments that a particular piece attracts. See supra notes 297-98 and accompanying text. This last feature could save researchers time by providing a standard by which to narrow archival searches (a law professor could essentially tell the archive, "retrieve all four-star articles on affirmative action").

335 E-mail from Paul Ginsparg to Bernard Hibbitts (Dec. 1, 1995) (on file with author). Ginsparg has also estimated that with a gigabyte of hard disk storage space currently costing less than $\$ 500,25,000$ physics papers can be stored on such a disk at a cost of less than two cents apiece. Paul Ginsparg, Winners and Losers in the Global Research Village, <http://xxx.lanl.gov/blurb/pg96unesco.html> (May 8, 1996) (text of presentation made at UNESCO Headquarters, Paris). Ginsparg has since estimated that the same gigabyte of disk space could accommodate 10,000 papers the size of the present one (roughly 423 kilobytes compressible to 82 kilobytes). E-mail from Paul Ginsparg to Bernard Hibbitts (Apr. 24, 1996) (on file with author). 
pieces over which copyright has been retained) republishing its own scholarship on the site. In that way, the site-sponsoring school could seize the technological high ground insofar as inquisitive and ambitious scholars from other law schools, other disciplines, and other countries, drawn to the site for its potential and its convenience, would (if the site were properly constructed) encounter the sponsoring school's intellectual products, perhaps for the first time.

Last but not least, even the editors of contemporary print-based law reviews have a positive role they can play in the transition to a new system of electronically self-published legal scholarship. ${ }^{336}$ Far from voluntarily and immediately folding up, they should continue their incipient efforts to place their published scholarship on the Web; not only, in fact, should they post whatever new scholarship continues to appear in their pages over the next few years, but they should put on a complete run of their back issues (perhaps making the articles in those issues hypertext compatible by converting into hyperlinks their footnotes and their citations to other articles in the same journal). Such a strategy would have two important results: first, it would make the Web a better (and more frequently used) resource for legal scholarship (which would in turn help to subtly acclimate legal scholars to the idea of using it as a publishing base); second, it would make the Web a richer publishing tool by giving legal scholars more literature accessible by hypertext links. As for the (student or faculty) editors of second-generation electronic law reviews with no print equivalents, they too should continue their work for as long as at least some scholars are willing to feed them material. The more established they become, the more established the Web itself will appear; in this context, they might do as much to encourage the success of Web selfpublishing in the long run as they might do to distract certain scholars from it in the short run.

Ultimately, however, the practice of self-publishing legal scholarship on the World Wide Web will almost certainly bring about the end of the law review as we know it, in both its print and electronic

336 Obviously, they could choose to play a negative role-in particular, by embracing the strategy of the "preemptive strike" already launched by the New England Journal of Medicine against self-published electronic scholarship in the health sciences-although it is to be hoped that scholarly responsibility and even their own self-interests as law students and law professors will prevail over the simple instinct for institutional self-preservation. The California Law Review recently demonstrated its mature attitude in this respect by printing an article by Robert Berring which had previously been made available in draft on the Internet. See Robert Berring, On Not Throwing Out the Baby: Planning the Future of

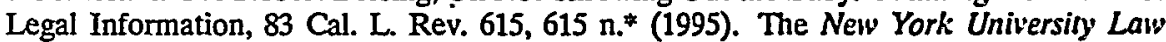
Review has obviously adopted the same commendable attitude in printing the present piece. 
forms.337 When will that end come? Providing they are attractive, convenient, and not too expensive, new technologies can disrupt traditional media very quickly-just consider how rapidly CDs replaced vinyl LPs in the entertainment industry. Even in the ostensibly more conservative academic context, new technologies which solve fundamental problems and create new opportunities for professors and their institutions can change scholarly norms in a stunningly short snippet of time. For instance, the 1991 creation of Paul Ginsparg's cheap and speedy electronic archive put the printed high-energy physics journals on the ropes almost immediately; four years after the inauguration of his service they have not collapsed, but they have been reduced to the status of sideshows and their demise appears inevitable. In actuality, it is still too early to say exactly when the law review in its present form will pass from the American academic scene, but in light of its critical condition and the availability of an alternative and arguably superior form of scholarly communication, it is not too early for the last writes.

337 This is not to say that the law review might not survive in some radically altered form with which we are not now familiar. It could, for instance, continue as a high-status ceremonial or archival mode of publication (e.g., a "deluxe edition" or a festschrift of especially famous essays). Alternatively, it might continue as a collection of student-written reviews-or, somewhat less ambitiously, a student- or faculty-selected list-of recommended self-published articles. This format might prove very appealing in an informationrich Internet environment. In this context, law review staffers-along with individual professorial (post-hoc) peer reviewers-would be performing a function somewhat akin to book or film reviewers who judge and comment on works after the fact, without having any control over whether or how they appear. See generally Jacques Leslie, Goodbye, Gutenberg, Wired 2.10, Oct. 1994, at 68,69 (quoting James J. O'Donnell, co-editor of the Bryn Mawr Classical Review: "[T] he journal model will evolve toward not a publishing operation but a gatekeeping operation'-that is, the journal's role will be to single out from the morass of information available on the Net those articles worthy of its imprimatur."). 